\title{
PROVISIONAL PRECEDENT: PROTECTING FLEXIBILITY IN ADMINISTRATIVE POLICYMAKING
}

\author{
KenNeth A. BambergeR*
}

\begin{abstract}
the rule of strict stare decisis, when a court construes a statute before an agency does, the judicial interpretation becomes binding precedent, even when Congress has delegated primary interpretive authority to the agency. In this Article, Kenneth Bamberger argues that the Supreme Court's adherence to this strict rule of precedent for the interpretations of administrative statutes undermines the separation-ofpowers justifications for agency administration and jeopardizes effective policymaking. He illustrates how the Supreme Court's decision in United States v. Mead, which limits the types of agency constructions that deserve judicial deference, dramatically increases the opportunities for courts to interpret statutes on their own. In response to the constitutional and normative disconnects caused by judges' enhanced ability to commandeer agency discretion, Bamberger proposes a model of provisional precedent as an alternative to strict stare decisis. This approach, based on the federalism model that governs federal court adjudication of state law issues, gives stare decisis effect to reasonable judicial constructions of regulatory statutes only until governing agencies make binding interpretations of their own.
\end{abstract}

\section{INTRODUCTION}

The doctrine of judicial precedent operates according to certain principles: Legal terms have only a single meaning, and, under Marbury v. Madison, ${ }^{1}$ courts "say" what that meaning "is." In Justice Story's words, the judiciary determines the "true construction of the laws," which then "bind[s] future cases of the same nature."3

These principles have had particular force in the statutory interpretation context. There, the Supreme Court has adopted the notion that judicial constructions of statutes are incorporated into the legisla-

* Associate, Wilmer, Cutler \& Pickering. B.A., 1998, Harvard University; Henry Fellow, 1990-1991, Cambridge University; J.D., 1998, Harvard Law School.

I wish to thank Ariela Dubler, Richard Fallon, Noah Feldman, Jesse Furman, Elena Kagan, Trevor Morrison, Fred Schauer, Tim Simeone, Laurence Tribe, Molly Van Houweling, Phil Weiser, Michael Bamberger, and Phylis Skloot Bamberger for their generous and helpful comments on earlier drafts, and Richard J. Pierce, Jr., Todd Rakoff, David Shapiro, and Ed Kneedler for help in shaping this Article's inquiry.

15 U.S. (1 Cranch) 137 (1803).

2 Id. at 177 ("It is emphatically the province and duty of the judicial department to say what the law is.").

31 Joseph Story, Commentaries on the Constitution of the United States $\S 377$ (photo. reprint 1991) (1833). 
tion itself. Under this "incorporation" approach, ${ }^{4}$ courts' interpretations become "part of the warp and woof of the legislation," 5 and in certain respects "as much a part of the statute as the text itself." 6 The statute "now says what the court has prescribed"7 until Congress amends it.

The deference doctrine adopted by the Supreme Court in Chevron U.S.A., Inc. v. Natural Resources Defense Council, Inc. ${ }^{8}$ operates according to different principles: ambiguous terms in regulatory statutes can bear multiple meanings; the choice between them is appropriately guided by policy concerns; and those policy choices belong to the political branches, notably to executive agencies, rather than to the judiciary. 9

Chevron provided a separation-of-powers grounding for the administrative state. Because Congress, the branch of government vested by the Constitution with the power to make laws, ${ }^{10}$ delegates primary interpretive authority to agencies when it leaves ambiguity in regulatory statutes, agency policymaking has a protected place within our constitutional scheme. When Chevron applies, courts are prohibited from substituting their own statutory constructions for an agency's reasonable interpretation. ${ }^{11}$ Agencies, not courts, get to interpret statutory ambiguity "first and foremost."12

Despite Chevron's profound departure from the general principle that courts are the primary interpreters of the law, ${ }^{13}$ the Supreme

4 See Thomas W. Merrill, Judicial Opinions as Binding Law and as Explanations for Judgments, 15 Cardozo L. Rev. 43, 44 (1993) ("The 'incorporation' conception posits that judicial constructions of enacted law enter into and become part of the instrument being construed.").

5 Francis v. S. Pac. Co., 333 U.S. 445, 450 (1948).

6 As the Court explained in Douglass v. County of Pike:

After a statute has been settled by judicial construction, the construction becomes, so far as contract rights acquired under it are concerned, as much a part of the statute as the text itself, and a change of decision is to all intents and purposes the same in its effect on contracts as an amendment of the law by means of a legislative enactment.

101 U.S. 677, 687 (1879).

7 United States v. Mead Corp., 533 U.S. 218, 247 (2001) (Scalia, J., dissenting).

8467 U.S. 837 (1984).

9 See id. at 842-44; see also infra Part I.B.

10 U.S. Const. art. I, $\S 1$ ("All legislative Powers herein granted shall be vested in a Congress of the United States .....").

11 Chevron, 467 U.S. at 844.

12 Smiley v. Citibank (S.D.), N.A., 517 U.S. 735, 740-41 (1996).

13 See Jonathan T. Molot, The Judicial Perspective in the Administrative State: Reconciling Modern Doctrines of Deference with the Judiciary's Structural Role, 53 Stan. L. Rev. 1,8 (2000) (arguing that Chevron model departs from "the Founders' original design for judicial influence"); Cass R. Sunstein, Law and Administration After Chevron, 90 Colum. L. Rev. 2071, 2074-75 (1990) (coining oft-used moniker for Chevron as "a kind 
Court has refused to modify its incorporation approach to precedent when a court gets the opportunity to address statutory ambiguity before an agency makes a binding interpretation. Thus, although the Court has held unanimously that the "whole point" of Chevron's rule of deference "is to leave the discretion provided by the ambiguities of a statute with the implementing agency," 14 it also has ruled that, when a court resolves an ambiguous provision first, the agency's ability to construe that provision-even by notice-and-comment rules of the type to which Chevron says courts must defer-is then foreclosed. ${ }^{15}$ As Justice Scalia explains, "[o]nce the court has spoken, it becomes unlawful for the agency to take a contradictory position."16 This strong contention appends a subversive codicil to Chevron's rule that Congress gives agencies, rather than courts, "whatever degree of discretion the ambiguity allows"17_that is, unless courts take it first.

Determining regulatory policy by means of such a winner-takesall race to the courtroom undermines the logic of the administrative state, a logic that delegates flexible decisionmaking power to expert administrators. Yet under governing case law, when a question of administrative policy arrives first before the bench, a judge's determination replaces that of the expert, not just in the individual case, but so long as the statute itself remains unaltered. ${ }^{18}$ Accordingly, applying incorporation theory wholesale to judicial interpretations of administrative statutes after Chevron permits the judiciary to commandeer the discretion delegated to agencies by Congress, flouting the recognized intent of the legislative branch and impinging on the prerogatives of the executive. ${ }^{19}$

of . . . counter-Marbury for the administrative state"); see also Cynthia R. Farina, Statutory Interpretation and the Balance of Power in the Administrative State, 89 Colum. L. Rev. 452, 462-63 (1989) (arguing that Chevron relegates judiciary "to little more than serving as a mouthpiece for legislative directives that are unequivocal and directly on point"); Thomas W. Merrill, Judicial Deference to Executive Precedent, 101 Yale L.J. 969, 969-70 (1992) (contending that "[Chevron] make[s] administrative actors the primary interpreters of federal statutes," which "relegate[s] courts to the largely inert role of enforcing unambiguous statutory terms"); Kenneth W. Starr, Judicial Review in the Post-Chevron Era, 3 Yale J. on Reg. 283, 283 (1986) ("[T] he Executive Branch ... is displacing the judiciary in its traditional and jealously guarded law-declaring function.").

14 Smiley, 517 U.S. at 742 (emphasis added).

15 See, e.g., Neal v. United States, 516 U.S. 284, 295 (1996) ("Once we have determined a statute's meaning, we adhere to our ruling under the doctrine of stare decisis, and we assess an agency's later interpretation of the statute against that settled law." (citations omitted)).

16 United States v. Mead Corp., 533 U.S. 218, 247 (2001) (Scalia, J., dissenting).

17 Smiley, 517 U.S. at 741.

18 Either Congress or a superior court may make such an alteration.

19 The incorporation theory underlying "super-strong" stare decisis is, in any context, vulnerable to criticism. See, e.g., Merrill, supra note 4, at 62-65. The theory is logically 
This doctrinal conflict has smoldered in the background of administrative law jurisprudence, most clearly visible recently in the few judicial attempts to resolve textual ambiguity even as the agency responsible for a statute's administration engaged in ongoing rulemaking proceedings. ${ }^{20}$

After the Supreme Court's recent articulation of the Chevron rule in United States v. Mead Corp. ${ }^{21}$ however, the practical consequences of the clash have been thrown into full relief. Mead limited the types of agency interpretations that are binding on courts, ${ }^{22}$ thereby increasing significantly the frequency with which courts will be able to resolve ambiguity preclusively before an agency can act decisively. The decision creates the widespread potential for courtsnow unfettered by binding agency constructions-to resolve statutory ambiguity independently. In the months since Mead was decided alone, courts have reached independent constructions of dozens of provisions in the environment, tax, energy, and many other substantive spheres in statutes otherwise committed to agency administration. 23

This Article argues that adherence to the incorporation rule after Mead undermines the constitutional premises and normative justifications for administrative policymaking. Such adherence promises a pervasive shift of interpretive authority from agencies to courts, defying the delegation of that authority to administrative bodies by Congress and ignoring the constitutional separation-of-powers principles

undermined by the fact that, while language that is really incorporated into the text of a law (by legislative enactment) must be followed by courts if constitutional, those same courts are not actually bound to follow "incorporated" judicial constructions. See, e.g., Helvering v. Hallock, 309 U.S. 106, 119 (1940) ("[S]tare decisis is a principle of policy and not a mechanical formula of adherence to the latest decision ...."). One need not reject the incorporation concept outright, or the broader notion of strong stare decisis, however, to accept my criticisms of its application in the administrative law context.

20 For example, the Tenth Circuit's decision in Southern Utah Wilderness Alliance v. Dabney, 222 F.3d 819 (10th Cir. 2000), which set standards for management of backcountry national park lands, was handed down before the National Park Service completed its rulemaking. See Notice of Availability of Draft National Park Service Management Policies, 65 Fed. Reg. 2984 (Jan. 19, 2000). The Ninth Circuit's decision in Aguirre-Cervantes v. INS, 242 F.3d 1169 (9th Cir. 2001), construing the terms "persecution" and "particular social group," was handed down before the INS completed its rulemaking. See Asylum and Withholding Definitions, 65 Fed. Reg. 76,588, 76,592 (proposed December 7, 2000) (to be codified at 8 C.F.R. pt. 208). Pursuant to the stipulation of the parties, the subsequent panel decision, Aguirre-Cervantes v. INS, 270 F.3d 794 (9th Cir. 2001), was vacated and remanded for further administrative proceedings. See Aguirre-Cervantes v. INS, 273 F.3d 1220 (9th Cir. 2001).

21533 U.S. 218 (2001).

22 See infra notes 163-88 and accompanying text.

23 See infra notes 223-35 and accompanying text. 
underlying Chevron and reaffirmed in Mead. ${ }^{24}$ It further threatens, across a host of substantive areas, to replace administrative flexibility with unchanging judicial rules, freezing regulatory policy even as science, society, and policy evolve.

The Article then proposes an alternative that is consistent with those constitutional and policy values: a model of "provisional precedent" based on the federalism model that governs federal court adjudication of state law issues. Under this model, a court's choice of one reasonable construction of regulatory statutes would not deprive the responsible agency of prospective decisionmaking authority. It would, instead, have stare decisis effect only until that agency sets forth its own permissible interpretation in a manner binding on the judiciary. ${ }^{25}$

24 Two articles written before Mead have identified the policy tensions between stare decisis and Chevron. Professor Richard Pierce has compared the values promoted by stare decisis and those embodied in Chevron and provided a thorough analysis of the pre-1997 cases considering these tensions. Richard J. Pierce, Jr., Reconciling Chevron and Stare Decisis, 85 Geo. L.J. 2225 (1997). His article suggests (in the pre-Mead context) that any apparent conflict between these values can be resolved in practice if courts view the existence of a conflict between an agency interpretation and a judicial precedent as an invitation to reconsider that precedent. See id. at 2260 (following lead of, e.g., Second Circuit in Aguirre v. INS, 79 F.3d 315, 317 (2d Cir. 1996) ("[Chevron] cannot compel a court to forgo the principle of stare decisis and abandon a construction previously made. . . But we are not prevented from making an independent decision whether a particular case now requires a revised reading of the statute.")).

Professor Rebecca Hanner White suggests that Chevron deference be understood as "just one canon of statutory construction" to which another such canon-stare decisisprovides an "exception." Rebecca Hanner White, The Stare Decisis "Exception" to the Chevron Deference Rule, 44 Fla. L. Rev. 723, 725 (1992). Because, however, "a stare decisis 'exception' to Chevron has the potential to swallow the rule," Professor White suggests that Chevron deference should be accorded to an "agency's construction of the Court's precedents as well as to the agency's construction of the statute it administers." Id. at 727; see also Thomas W. Merrill \& Kristin E. Hickman, Chevron's Domain, 89 Geo. L.J. 833,917 (2001) (arguing-also pre-Mead-in favor of Supreme Court's approach to date and for "blanket presumption" that all past Supreme Court precedents are binding); infra notes 136-38 and accompanying text (discussing argument of Merrill and Hickman).

25 This proposal arises in the context of a vigorous debate on the "fundamental" question of "the extent to which the executive branch should consider judicial pronouncements (and judgments) controlling on its interpretation of the law." Randolph D. Moss, Executive Branch Legal Interpretation: A Perspective from the Office of Legal Counsel, 52 Admin. L. Rev. 1303, 1304-05 (2000). See generally Merrill, supra note 4 (describing debate between those who conceive interpretations contained in judicial opinions as "binding" on executive branch and those who believe that interpretations contained in judicial opinions are nonbinding "explanations" for final judgments). Yet my argument is at once narrower and more far-reaching than the categorical contention-at one end of the debate-that "[t]he Supreme Court's interpretations of ... federal statutes ... do not bind the President any more than the President's or Congress's interpretations bind the courts." Michael Stokes Paulsen, The Most Dangerous Branch: Executive Power to Say What the Law Is, 83 Geo. L.J. 217, 221 (1994); see also Merrill, supra note 4 (concluding that judicial opinions are explanations, rather than binding law); Herbert Wechsler, The Courts and the Constitution, 65 Colum. L. Rev. 1001, 1008 (1965) (rejecting view that Supreme Court's decisions require "obedience by all within the purview of the rule that is declared"). It is 
Part I explores the doctrinal premises of the incorporation approach to judicial precedent and of Chevron's competing vision of judicial power and interpretive legitimacy. Part II demonstrates how, after Mead, the Court's decision to continue applying the preChevron incorporation theory of precedent undercuts the constitutional and normative values underlying administrative policymaking. Part III argues for the application of the federalism model to the judicial review of administrative action and responds to a number of objections. Specifically, it contends that such a theory best guards against the illegitimate aggrandizement of judicial authority, advances the Court's own understanding of administrative discretion, and furthers the policy benefits derived from agency expertise, political oversight, and policy flexibility in the face of changing circumstances.

COMPETING Visions OF STATUTORY INTERPRETATION:

Definitive Judicial Precedent vs. Dynamic ADMINISTRATIVE Policy

\section{A. The Incorporation Theory of Precedent:}

\section{A Super-Strong Rule of Stare Decisis for Statutory Precedents}

The idea that judicial declarations of the law establish "permanent rule[s], which it is not in the breast of any subsequent judge to alter or vary from according to his private sentiments," 26 claims a common law pedigree dating at least to Blackstone and Kent. ${ }^{27}$ In our legal system, the determination of legal meaning falls within the "proper and peculiar province of the courts," 28 which apply an arsenal of "tools available for the resolution of . . . doubt" 29 in order to isolate "rules and precedents" that bind future legal actors. ${ }^{30}$

narrower in that it does not claim that judicial decisions cannot bind the executive. Yet it is deeper in claiming that reasonable judicial constructions can be set aside by agencies, after which they would no longer bind either the executive branch or the very court that issued them.

261 William Blackstone, Commentaries $* 69$.

27 See id.; 1 James Kent, Commentaries on American Law *475 ("A solemn decision upon a point of law, arising in any given case, becomes an authority in a like case, because it is the highest evidence which we can have of the law applicable to the subject...."). See generally Thomas R. Lee, Stare Decisis in Historical Perspective: From the Founding Era to the Rehnquist Court, 52 Vand. L. Rev. 647, 662-66 (1999).

28 The Federalist No. 78, bk. 2, at 101 (Alexander Hamilton) (Tudor Publ'g Co. 1937); see also Marbury v. Madison, 5 U.S. (1 Cranch) 137, 177 (1803).

29 Almendarez-Torres v. United States, 523 U.S. 224, 234 (1998) (quoting Bhd. of R.R. Trainmen v. Balt. \& Ohio R.R., 331 U.S. 519, 529 (1947)).

30 The Federalist No. 78 , supra note 28 , bk. 2, at 105 (contending that in order to "avoid an arbitrary discretion," later courts must be "bound down by strict rules and precedents"). 
These principles apply with "special force in the area of statutory interpretation." 31 In this context, the Supreme Court has adopted the strong notion that when a court exercises the judicial power to settle on a text's meaning, the "statute to that extent becomes more determinate, or, if you will, amended to the extent of the Court's decision."32 Conceptually, then, any departure from a settled interpretation constitutes a deviation from the meaning of the statute itself.

This incorporation conception of statutory precedents is grounded in a number of foundational understandings about the nature of, and limits on, judicial power. While courts enjoy the primary authority to "say what the law is," 33 they must remain bound by their declarations, lest judicial authority devolve, in Hamilton's words, into "arbitrary discretion." 34 Under the incorporation approach, once a court "give[s its] view on the meaning of a statute, [its] task is concluded, absent extraordinary circumstances. When the [c]ourt changes its mind years later, simply because the judges have changed . . . it takes upon itself the function of the legislature." 35

The lawmaking function, of course, belongs to Congress. When a court has determined statutory meaning-"unlike in the context of constitutional interpretation"-Congress remains "free to alter what [the court] ha[s] done." 36 Because Congress's decision not to overrule a judicial construction may be taken as presumptive acquiescence to it, subsequent judicial reinterpretation of that same construction constitutes a particularly egregious encroachment on the legislative prerogative. ${ }^{37}$

31 Patterson v. McLean Credit Union, 491 U.S. 164, 172 (1989). In contrast to the weaker precedential force accorded to constitutional decisions, "the normal presumption of stare decisis" applies to decisions construing statutes. NLRB v. Int'l Longshoremen's Ass'n, 473 U.S. 61, 84 (1985).

32 Frank E. Horack, Jr., Congressional Silence: A Tool of Judicial Supremacy, 25 Tex. L. Rev. 247, 250 (1947); see also supra notes 5-7 and accompanying text; infra notes 35-37 and accompanying text.

33 Marbury, 5 U.S. (1 Cranch) at 177.

34 The Federalist No. 78, supra note 28, bk. 2, at 105; see also Anastasoff v. United States, 223 F.3d 898, 903 (8th Cir.), vacated as moot en banc, 235 F.3d 1054 (8th Cir. 2000) ("The duty of courts to follow their prior decisions was understood [in the late eighteenth century] to derive from the nature of the judicial power itself and to separate it from a dangerous union with the legislative power.").

35 Boys Mkts., Inc. v. Retail Clerks Union, Local 770, 398 U.S. 235, 258 (1970) (Black, J., dissenting); see also Horack, supra note 32, at 250-51 (arguing that "the functional consequences" of abandoning judicial precedent "are legislative rather than judicial"). But see William N. Eskridge, Jr., Overruling Statutory Precedents, 76 Geo. L.J. 1361, 1366 (1988) (criticizing this argument as "excessively mechanical").

36 Patterson, 491 U.S. at 172-73.

37 As the Court explained in Johnson v. Transportation Agency, for example: 
Moreover, both Congress and private parties will have shaped their behavior on a court's interpretation of statutory meaning. In this sense, judicial constructions, like the positive enactments underlying them, create significant reliance interests; overruling these constructions "unsettle[s] a vast cluster of public and private expectations." 38 Once again, it falls within the legislative, rather than judicial, function to extinguish such interests, subject to the constraints of the Constitution.

Thus, in most contexts stare decisis constitutes only a "wise policy" reflecting the general understanding that "in most matters it is more important that the applicable rule of law be settled than that it be settled right." 39 Yet the Supreme Court has held that the particular implications of statutory interpretation for the separation of powers ordered in the Constitution require a "super-strong" rule of precedent for judicial constructions of legislative statutes. ${ }^{40}$

\section{B. Understanding Chevron's Vision: Separation of Powers and the Administrative State}

In Chevron, the Supreme Court articulated a vision of statutory construction rooted in very different premises than the doctrine of incorporation. Chevron premised administrative policymaking on the congressional delegation of primary interpretative authority to agencies and the propriety of resolving statutory ambiguity in light of

[I]f the Court has misperceived the political will, it has the assurance that because the question is statutory Congress may set a different course if it so chooses. Congress has not amended the statute to reject our construction, nor have any such amendments even been proposed, and we therefore may assume that our interpretation was correct.

480 U.S. 616, 629 n.7 (1987) (internal quotations omitted); see also, e.g., Toolson v. N.Y. Yankees, Inc., 346 U.S. 356, 357 (1953) (per curiam) (citing legislative acquiescence to precedent holding baseball team exempt from antitrust laws and stating that "if there are evils in this field which now warrant application to it of the antitrust laws it should be by legislation"); Apex Hosiery Co. v. Leader, 310 U.S. 469, 488-89 (1940) (declining to alter application of Sherman Act to labor unions because Congress was aware of controversy and did not legislate to resolve it).

38 Eskridge, supra note 35, at 1367 (summarizing argument set forth in Edward H. Levi, An Introduction to Legal Reasoning, 15 U. Chi. L. Rev. 501, 523-40 (1948), that statutes should not be reinterpreted unless original interpretation is unconstitutional).

39 Burnet v. Coronado Oil \& Gas Co., 285 U.S. 393, 405-06 (1932) (Brandeis, J., dissenting); see Agostini v. Felton, 521 U.S. 203, 235 (1997) (asserting that "stare decisis is not an inexorable command" (quoting Payne v. Tennessee, 501 U.S. 808, 828 (1991))); Payne, 501 U.S. at 827 ("[S]tare decisis is the preferred course because it promotes the evenhanded, predictable, and consistent development of legal principles, fosters reliance on judicial decisions, and contributes to the actual and perceived integrity of the judicial process.").

40 William N. Eskridge, Jr., Dynamic Statutory Interpretation 253 (1994). See also the cases cited in supra note 37. 
evolving societal, political, and technological circumstances. While the incorporation approach envisions judicial interpretation as definitive, Chevron requires judicial deference to the reasonable choices made by agencies pursuant to legislative delegation. Chevron thus adopted a view of administrative policymaking with significant implications for the relationship between courts and the political branches.

\section{Chevron's Break with the Past}

\section{a. The Pre-Chevron Regime}

Since the advent of regulatory responses to "the social and economic questions that flowed from the era of mechanical invention,"41 courts and commentators have struggled to find a comfortable fit between administrative agency decisionmaking and the Constitution's tripartite system of powers. ${ }^{42}$

Uncertainty about the location of agencies within the constitutional scheme resulted, before Chevron was decided, in a variety of judicial standards for reviewing administrative action. Perceiving an analog between administrative adjudicators and judicial magistrates, courts reviewed agency findings of fact deferentially ${ }^{43}$ and "naked question[s] of law" de novo. ${ }^{44}$ Embracing policy expertise as a justification for administrative execution of regulatory statutes, courts reviewed most other determinations of statutory meaning under the doctrine of Skidmore v. Swift \& Co., which hinged judicial deference on an agency construction's "power to persuade," 45 turning on a variety of factors such as "the degree of the agency's care, its consistency, formality, and relative expertness." 46 And recognizing that Congress occasionally delegates legislative-type power to an agency explicitlysuch as the task of defining "unemployment" for purposes of Aid to

41 James M. Landis, The Administrative Process 7 (1938).

42 See A. Christopher Bryant \& Timothy J. Simeone, Remanding to Congress: The Supreme Court's New "On the Record" Constitutional Review of Federal Statutes, 86 Cornell L. Rev. 328, 370-71 (2001) (providing summary of discourse regarding place of agencies in constitutional structure).

43 See, e.g., Crowell v. Benson, 285 U.S. 22, 46 (1932) (deferring to deputy commissioner's findings, as "[t]o hold otherwise would be to defeat the obvious purpose of the legislation").

44 Packard Motor Car Co. v. NLRB, 330 U.S. 485 (1947) (considering whether foremen were "employees" under the language of the National Labor Relations Act); see also Roy A. Schotland, Scope of Review of Administrative Action-Remarks Before the D.C. Circuit Judicial Conference (Mar. 18, 1974), in 34 Fed. B.J. 54, 58 (1975) ("[L]aw-declaring, which has to do with general construction of a statute wholly independently of the particular controversy at bar . . . will be mainly, and very often entirely, for our best experts at such matters as statutory construction, you judges . . . .").

45323 U.S. 134, 140 (1944).

46 United States v. Mead Corp., 533 U.S. 218, 228 (2001). 
Families with Dependent Children eligibility ${ }^{47}$-courts accorded the resulting determinations "more than mere deference or weight." 48 They could set aside those decisions only if arbitrary or capricious, an abuse of discretion, or outside the authority conveyed by the governing statute. 49

Thus, except in the rare case in which Congress expressly indicated otherwise, pre-Chevron courts-while often sustaining agency constructions as a matter of practice-retained primary authority over statutory interpretation, including the threshold questions of whether agency constructions were relevant or convincing.50 As Judge Friendly summarized the legal landscape eight years before Chevron was decided, although in some cases the Supreme Court regarded the application of the law to particular facts as the province of agencies and deserving of "great deference," there was "an impressive body of law sanctioning free substitution of judicial for administrative judgment when the question involve[d] the meaning of a statutory term." 51

\section{b. Chevron's Rule: Separation of Powers as a Constitutional} and Normative Justification for Administrative Policymaking

The license for free substitution of judicial judgment ended with Chevron. That case established the presumption that an ambiguity or gap in a statute indicates an implicit "legislative delegation" of power to interpret that statutory provision to the agency charged with the statute's administration. .2 "We accord deference to agencies under Chevron," a unanimous Supreme Court held in 1996, "because of a presumption that Congress, when it left ambiguity in a statute meant for implementation by an agency, understood that the ambiguity would be resolved, first and foremost, by the agency." 53

47 See Batterton v. Francis, 432 U.S. 416, 425-26 (1977).

48 Id. at 426.

49 Id.; see also Chevron U.S.A., Inc. v. Natural Res. Def. Council, Inc., 467 U.S. 837, 843-44 (1984) (noting that, where Congress has explicitly delegated decisions to agency, applicable standard of review is whether regulation is "arbitrary, capricious, or manifestly contrary to the statute").

50 See NLRB v. Hearst Publ'ns, Inc., 322 U.S. 111, 130-31 (1944) (declaring that questions of statutory interpretation are "[u]ndoubtedly . . . for the courts to resolve," while giving "appropriate" weight to agency charged with administering questioned statute); Pittston Stevedoring Corp. v. Dellaventura, 544 F.2d 35, 49 (2d Cir. 1976) (recognizing that Supreme Court decisions governing scope of review of agency actions "are analytically in conflict" such that courts "must choose the one it deems more appropriate for the case at hand"), aff'd sub nom. Northeast Marine Terminal Co. v. Caputo, 432 U.S. 249 (1977); see also Merrill \& Hickman, supra note 24, at 833 ("In other words, deference . . . was grounded in the exercise of judicial discretion.").

51 Pittston Stevedoring, 544 F.2d at 49.

52 Chevron, 467 U.S. at 842-44.

53 Smiley v. Citibank (S.D.), N.A., 517 U.S. 735, 740-41 (1996). 
The judiciary must therefore read statutes with the understanding that "the agency (rather than the courts) ... possess[es] whatever degree of discretion the ambiguity allows." ${ }^{54}$ Accordingly, while a preChevron court was left to "choose the [standard of review] it deem[ed] more appropriate for the case at hand,"5s Chevron's nowroutine two-step process ${ }^{56}$ limits the judicial role: Courts must give effect to congressional intent when that intent is "clear"57 and to reasonable agency interpretations when it is not.

Certainly, Chevron did not abandon the pre-existing notion that agencies bring special knowledge and expertise to policymaking. In fact, it referenced that fact to justify its presumption that Congress intends agencies to resolve ambiguity in statutes. ${ }^{58}$ Yet by taking the extra step to ground agency interpretive authority and judicial deference on legislative intent-and no longer premising it entirely on factors such as administrative expertise-Chevron explicitly invoked fundamental constitutional doctrines governing relations among the governmental branches. 59

54 Id. at 741.

55 Pittston Stevedoring, 544 F.2d at 49.

56 Chevron's two-step approach is as follows:

First, always, is the question whether Congress has directly spoken to the precise question at issue. If the intent of Congress is clear, that is the end of the matter; for the court, as well as the agency, must give effect to the unambiguously expressed intent of Congress. If, however, the court determines Congress has not directly addressed the precise question at issue, the court does not simply impose its own construction on the statute, as would be necessary in the absence of an administrative interpretation. Rather, if the statute is silent or ambiguous with respect to the specific issue, the question for the court is whether the agency's answer is based on a permissible construction of the statute.

Chevron, 467 U.S. at 842-43.

57 Id. at 842; see also Chem. Mfrs. Ass'n v. Natural Res. Def. Council, Inc., 470 U.S. 116,125 (1985) ("Of course, if Congress has clearly expressed an intent contrary to that of the Agency, our duty is to enforce the will of Congress.").

58 See Chevron, 467 U.S. at 844 (discussing long-standing practice of deference to administrative interpretations "whenever decision as to the meaning or reach of a statute has involved reconciling conflicting policies, and a full understanding of the force of the statutory policy in the given situation has depended upon more than ordinary knowledge respecting the matters subjected to agency regulations" (quoting United States v. Shimer, 367 U.S. 374, 382 (1961))); see also John F. Manning, Constitutional Structure and Judicial Deference to Agency Interpretations of Agency Rules, 96 Colum. L. Rev. 612, 626 (1996) ("While ascribing [its] presumption in part to the fact that judges are 'not experts in the field,' Chevron's reasoning devotes far greater emphasis to the broader assumptions underlying our structure of government." (quoting Chevron, 467 U.S. at 865)).

59 See Pierce, supra note 24 , at 2233 ("Chevron ... find[s] a constitutionally permissible place for agencies within the structure devised by the Framers.").

Certainly the scholarly literature analyzing Chevron has suggested numerous alternative doctrinal bases for a rule of judicial deference. See, e.g., Maureen B. Callahan, Must Federal Courts Defer to Agency Interpretations of Statutes?: A New Doctrinal Basis for 
As Professor Tribe has described, although Chevron's deference requirement "is not a rule of constitutional law per se, ... it is nonetheless premised on important separation-of-powers principles." 60 Specifically, Chevron premised deference by the judiciary (established by Article III of the Constitution) to decisions by agencies (which are not mentioned explicitly anywhere in the Constitution) on the intent of Congress (established by Article I of the Constitution).

This arrangement reflects both general notions of interbranch respect and specific understandings of the appropriate roles and capacities of the branches of government. ${ }^{61}$ To be sure, Chevron did not hold that the judiciary is constitutionally incompetent to entertain policy considerations in decisionmaking. ${ }^{62}$ Nonetheless, consistent with

Chevron U.S.A. v. Natural Resources Defense Council, 1991 Wis. L. Rev. 1275, 1278 ("Chevron's rule of required deference is better understood as a judicially self-imposed, prudential limitation on the federal courts' interpretive authority."); John F. Duffy, Administrative Common Law in Judicial Review, 77 Tex. L. Rev. 113, 200 (1998) (proposing "statutorily-based alternative" to Chevron, in which one need not invoke implicit delegations of power, but only agencies' explicit authority to promulgate rules); David J. Barron \& Elena Kagan, Chevron's Nondelegation Doctrine, 2001 Sup. Ct. Rev. 201, 234-57 (arguing, in light of policy assessments of appropriate allocation of power in administrative state, that deference question should turn on position in agency hierarchy of person assuming responsibility for administrative decision). See generally Merrill \& Hickman, supra note 24, at 863-73 (discussing debates over "Iegal foundation of the Chevron doctrine"). Yet for the purposes of this Article, which considers the tension between two doctrines as articulated by the Supreme Court, I follow the lead of other scholars who take as a starting point "the Court's own account for Chevron," William K. Kelley, Avoiding Constitutional Questions as a Three-Branch Problem, 86 Cornell L. Rev. 831, 870 n.232 (2001), rooted in notions of interbranch delegation and the separation of powers.

601 Laurence H. Tribe, American Constitutional Law 994 (3d ed. 2000); see also Manning, supra note 58, at 623 (calling Chevron doctrine "Constitutionally-Inspired Canon of Construction"). See generally, Jerry L. Mashaw, Textualism, Constitutionalism, and the Interpretation of Federal Statutes, 32 Wm. \& Mary L. Rev. 827, 837-38 (1991) (arguing that debates about norms governing judicial interpretation of federal statutes, including Chevron's principle, are at base about "constitutional values").

61 In the words of Professor Tribe:

Separation-of-powers principles have [a] pervasive [structural and substantive] effect because they involve the very structure of government, and nothing lies closer to the core of constitutional law-law that constitutes (that, in its Latin roots, causes things to come together and stand up)-than the system of divided and interlocking powers embodied in the framework of our government.

1 Tribe, supra note 60 , at 126.

62 Justice Scalia in fact proposed this interpretation of Chevron, only to knock it down.

He suggested:

One possible validating rationale ... [for Chevron] is that the constitutional principle of separation of powers requires Chevron. The argument goes something like this: When, in a statute to be implemented by an executive agency, Congress leaves an ambiguity that cannot be resolved by text or legislative history, .... the resolution of that ambiguity necessarily involves policy judgment. Under our democratic system, policy judgments are not for the courts but for the political branches; Congress having left the policy question open, it must be answered by the Executive. 
structural and normative conceptions-rooted in notions of competence, accountability, and democratic legitimacy-about the proper location of political decisionmaking, ${ }^{63}$ the Court held that policy choices left by gaps in a statute do not belong to "federal judges-who have no constituency."64 Rather, "[o]ur Constitution vests such responsibilities in the political branches." 65 Indeed,

Judges are not experts in the field, and are not part of either political branch of the Government. ... In contrast, an agency to which Congress has delegated policymaking responsibilities may, within the limits of that delegation, properly rely upon the incumbent administration's views of wise policy to inform its judgments. While agencies are not directly accountable to the people, the Chief Executive is, and it is entirely appropriate for this political branch of the Government to make such policy choices-resolving the competing interests which Congress itself either inadvertently did not resolve, or intentionally left to be resolved by the agency charged with the administration of the statute in light of everyday realities. ${ }^{66}$

Thus, with one doctrinal move-the presumption that Congress intends agencies to resolve statutory ambiguity "first and foremost"67-Chevron constructed a constitutional buttress to fortify the policy arguments about agency expertise and flexibility that previously had justified the primacy of extraconstitutional agency decisionmaking.

\section{Chevron's Implications: What Does It Mean to Delegate Primary Interpretive Authority to Agencies?}

As set forth above, pursuant to the separation-of-powers explanation for the administrative state, when agencies act in a manner Congress intended to be conclusive, courts are "obliged to accept the agency's position if Congress has not previously spoken to the point at

Antonin Scalia, Judicial Deference to Administrative Interpretations of Law, 1989 Duke L.J. 511, 514-15. He then argued, however, that "[p]olicy evaluation is . . part of the traditional judicial tool-kit that is used in applying the first step of Chevron-the step that determines, before deferring to agency judgment, whether the law is indeed ambiguous.... [I]t is not any constitutional impediment to 'policy-making' that explains Chevron." Id. at 515-16.

63 See Manning, supra note 58, at 626 ("Chevron's reasoning [stressed] . . broader assumptions underlying our structure of government. Specifically, the Court emphasized that our constitutional system favors relatively more accountable agencies, and not relatively less accountable courts, as repositories of policymaking discretion ...."); Starr, supra note 13, at 308-12 (discussing how Chevron shifts policymaking responsibility from courts "to democratically accountable officials" in agencies).

64 Chevron, 467 U.S. at 866.

65 Id. (quoting TVA v. Hill, 437 U.S. 153, 195 (1978)).

66 Chevron, 467 U.S. at 865-66.

67 Smiley v. Citibank (S.D.), N.A., 517 U.S. 735, 741 (1996). 
issue and the agency's interpretation is reasonable."68 Numerous decisions before and after Chevron have developed the implications of grounding the legitimacy of administrative policymaking in this congressional delegation of primary interpretive authority to agencies.

\section{a. The Model for Chevron's Separation-of-Powers Framework: Explicit Congressional Delegations of Interpretive Power}

Chevron's paradigm of an implicit congressional delegation of interpretive authority to agencies was not spun of whole cloth. To the contrary, that decision simply expanded the separation-of-powers model that the Supreme Court had applied since the beginning of the twentieth century to instances in which Congress explicitly assigned to agencies the power to construe regulatory statutes. As the Court had explained previously, where a statute includes such an "explicit delegation of substantive authority," the agency's "definition of [a statutory] term" is "entitled to 'legislative effect' because, '[i]n a situation of this kind, Congress entrusts to the [agency], rather than to the courts, the primary responsibility for interpreting the statutory term." 69

In this context, the Court has explored thoroughly the limits on judicial review effected by the legislative delegation of primary interpretive authority to agencies. Where the resolution of statutory ambiguity is committed to agency discretion, a reviewing court determines "whether the course followed by the [agency] is consistent with its mandate from Congress." 70 Beyond that, a court should ordinarily refrain from expressing even a "preliminary view on what ... policy permits"- such as would be necessary to issue an injunction- "before

68 United States v. Mead Corp., 533 U.S. 218, 229 (2001).

69 Schweiker v. Gray Panthers, 453 U.S. 34, 44 (1981) (some alterations in original) (quoting Batterton v. Francis, 432 U.S. 416, 425 (1977)). Schweiker reviewed an agency's definition of the term "available" in the Social Security Act's Medicaid provisions. See id.; see also Chevron, 467 U.S. at 843-44 ("If Congress has explicitly left a gap for the agency to fill, there is an express delegation of authority to the agency to elucidate a specific provision of the statute by regulation."); AT\&T Co. v. United States, 299 U.S. 232, 236-37 (1936) (explaining that Court may not second-guess discretion of agency acting within bounds of its administrative powers, provided agency action is not "so entirely at odds with fundamental principles of correct accounting'... as to be the expression of a whim rather than an exercise of judgment" (quoting Kansas City S. Ry. v. United States, 231 U.S. 423, 444 (1913))).

70 Atchison, Topeka \& Santa Fe Ry. v. Wichita Bd. of Trade, 412 U.S. 800, 806 (1973) (plurality opinion); see Chevron, 467 U.S. at $843-44$ (holding that courts may set aside agency decisions pursuant to express delegation only if they are "arbitrary, capricious, or manifestly contrary to the statute"); Batterton, 432 U.S. at 425-26 (stating that regulation made pursuant to express delegation is owed deference unless agency exceeded its authority or regulation is arbitrary or capricious, constitutes abuse of discretion, or is otherwise contrary to law). 
the [agency] expresses its view."71 This is because, under the doctrine of "primary jurisdiction,"72 the agency has been conferred primary authority by the "division of function which the legislature has made between the administrative body and the court of review." 73 Indeed, decisions predating Chevron by more than half a century make clear that where Congress expressly grants interpretive authority to an agency, courts are restricted to determining the legal limits of the agency's discretion and should avoid making binding pronouncements as to matters committed to that discretion. ${ }^{74}$

The most comprehensive discussion of what it means for Congress to commit a matter to agency discretion-and of the corresponding limits on courts' ability to make legal pronouncements binding future agency decisionmaking - appears in Justice Frankfurter's opinion for a unanimous Court in Federal Communications Commission v. Pottsville Broadcasting Co. ${ }^{75}$ Pottsville Broadcasting involved the FCC's express mandate under the Communications Act of 193476 to distribute radio licenses according to "public convenience, interest, or necessity."77 In its decision, the Court affirmed the D.C. Circuit's

71 Atchison, 412 U.S. at 821.

72 Id. at 820 .

73 Id. at 819-20 (quoting Scripps-Howard Radio, Inc. v. FCC, 316 U.S. 4, 10 (1942)). Pursuant to the doctrine of primary jurisdiction, the appropriate course for a court is usually to indicate any legal errors made by the agency and then remand to the agency so that it may set forth legislative policy within the scope of its discretion. As the Court described in Florida Power \& Light Co. v. Lorion:

If the record before the agency does not support the agency action, . . the proper course, except in rare circumstances, is to remand to the agency for additional investigation or explanation. The reviewing court is not generally empowered to conduct a de novo inquiry into the matter being reviewed and to reach its own conclusions based on such an inquiry.

470 U.S. 729, 744 (1985); see Port of Portland v. United States, 408 U.S. 811, 842 (1972) ("[I]t is not the role of this Court to arrive at its own determination of the public interest .... Our appellate function in administrative cases is limited to considering whether the announced grounds for the agency decision comport with the applicable legal principles."); cf. SEC v. Chenery Corp., 318 U.S. 80, 88 (1943) ("[A]n appellate court cannot intrude upon the domain which Congress has exclusively entrusted to an administrative agency.").

74 See, e.g., AT\&T, Co. v. United States, 299 U.S. 232, 236 (1936) ("This court is not at liberty to substitute its own discretion for that of administrative officers who have kept within the bounds of their administrative powers."); Ma-King Prods. Co. v. Blair, 271 U.S. 479, 483 (1926) (reviewing IRS ruling under legal error/"clearly arbitrary or capricious" standard); ICC v. Union Pac. R. Co., 222 U.S. 541, 547 (1912) (stating that Interstate Commerce Commission orders are final unless they exceed power that agency could constitutionally or statutorily exercise, or are based on mistake of law).

75309 U.S. 134 (1940).

76 Communications Act of 1934, Pub. L. No. 73-416, 48 Stat. 1064 (codified as amended at 47 U.S.C. $\$ \S 151-611(2001))$.

7747 U.S.C. $\$ 307$; Pottsville Broad. Co., 309 U.S. at 138 (internal quotations omitted). Justice Frankfurter recognized that, "[w]hile this criterion is as concrete as the complicated factors for judgment in such a field of delegated authority permit, it serves as a supple 
holding that the Commission had improperly based its denial of a license on an erroneous understanding of state law. ${ }^{78}$ However, the Court reversed the circuit's later mandamus order requiring the FCC to reassess the petitioner's application singly, rather than "on a comparative basis" with other applications. The choice of a competitive selection process, the Court held, lay within the FCC's discretion over how to serve the "public convenience, interest, or necessity."79

Justice Frankfurter took the opportunity to distinguish "the spheres of authority which Congress has given to the Commission and the courts" by its regulatory delegation. ${ }^{80} \mathrm{He}$ assessed the error below as follows: "The Court of Appeals invoked against the Commission the familiar doctrine that a lower court is bound to respect the mandate of an appellate tribunal and cannot reconsider questions which the mandate has laid at rest." 81 The doctrine, however, had no place in this case, because

[w] hat is in issue is not the relationship of federal courts inter se... but the due observance by courts of the distribution of authority made by Congress as between its power to regulate commerce and the reviewing power which it has conferred upon the courts under Article III of the Constitution. ${ }^{82}$

Thus, the Court rejected the notion that " $[\mathrm{t}]$ he technical rules derived from the interrelationship of judicial tribunals forming a hierarchical system" could be "mechanically applied to determine the extent to which Congressional power, exercised through a delegated agency, can be controlled within the limited scope of 'judicial power' conferred by Congress under the Constitution." 83 Quite the opposite. For "an administrative determination in which is imbedded a legal question open to judicial review does not impliedly foreclose the administrative agency, after its error has been corrected, from enforcing the legislative policy committed to its charge." 84

instrument for the exercise of discretion by the expert body which Congress has charged to carry out its legislative policy." Id.

78 The D.C. Circuit had rejected the FCC's reading of Pennsylvania law-which, of course, is not entrusted to the FCC to interpret-that led the FCC to find that the Pottsville Broadcasting Company was "financially disqualified." Id. at 139.

79 Id. at 145; see also id. at 138 (stating that issues like "the scope of the inquiry, whether applications should be heard contemporaneously or successively, [and] whether parties should be allowed to intervene in one another's proceedings," were "explicitly and by implication left to the Commission's own devising").

80 Id. at 136.

\$1 Id. at 140.

S2 Id. at 141.

83 Id.

84 Id. at 145. 
In light of these separation-of-powers limits on the judicial power, then, the idea that courts could, by incorporation, make binding decisions as to matters within the discretion of agencies, was expressly rejected:

The Court of Appeals cannot write the principle of priority [for earlier-filed broadcast applications] into the statute as an indirect result of its power to scrutinize legal errors in the first of an allowable series of administrative actions. ... It would mean that for practical purposes the contingencies of judicial review and of litigation, rather than the public interest, would be decisive factors in determining [such policy decisions]. ${ }^{85}$

Prior to Chevron, then, the Court had adopted the view that, where Congress explicitly delegated primary interpretive power to an agency, courts reviewing the agency's decisions should correct aspects that exceed the scope of administrative discretion, but otherwise leave matters open for agency resolution in the future.

\section{b. Extending the Explicit Delegation Doctrine to Implicit Delegations}

Chevron recognized that Congress need not explicitly delegate policy choices to administrative agencies in order to vest them with primary interpretive authority. ${ }^{86}$ In so doing, the Court extended the principle of deference to administrative choices made on the grounds of an express congressional delegation to decisions reached pursuant to congressional delegations made implicitly. ${ }^{87}$

As in the case when Congress expresses its intent explicitly, implicit delegations to agencies do not deprive courts of the power to determine the scope of the legislative delegation. As Chevron noted, the judiciary's "final authority on issues of statutory construction" means that it "must reject administrative constructions which are contrary to clear congressional intent." 88

But when Congress leaves ambiguity or gaps in the statute, the responsibility for making the resulting policy choices is "left to be re-

85 Id. at $145-46$

86 See Chevron U.S.A., Inc. v. Natural Res. Def. Council, Inc., 467 U.S. 837, 844 (1984) ("Sometimes the legislative delegation to an agency on a particular question is implicit rather than explicit.").

87 See id. at 842-44 (setting forth similar standards for explicit and implicit delegation); Michigan v. EPA, 268 F.3d 1075, 1082 (D.C. Cir. 2001) ("[W]hen Congress has explicitly or impliedly left a gap for an agency to fill ... 'any ensuing regulation is binding in the courts unless procedurally defective, arbitrary [and] capricious in substance, or manifestly contrary to the statute." (quoting United States v. Mead Corp., 533 U.S. 218, 227 (2001) (emphasis added) (alteration in original))).

88 Chevron, 467 U.S. at 843 n.9. 
solved by the agency charged with the administration of the statute in light of everyday realities." $\$$ So long as an agency acts within the scope of its delegation-satisfying the requirement of reasonableness ${ }^{90}$ and exercising power in a manner authorized by Congress-"a reviewing court has no business" rejecting an agency's resolution of a particular statutory ambiguity.91 "The whole point of Chevron," like the case law concerning explicit congressional delegations of authority before it, "is to leave the discretion provided by the ambiguities of a statute with the implementing agency."92

In fleshing out what it means to leave discretion with an agency, the Supreme Court has held in a number of contexts that neither an agency's action nor its inaction extinguishes administrative discretion to construe a statute reasonably in the future. Chevron itself, which involved a change in the EPA's interpretation of the statutory term "stationary source,"93 made clear that "[a]n initial agency interpretation is not instantly carved in stone." 94 To the contrary, inherent in an agency's discretion is the understanding that it "must consider varying interpretations and the wisdom of its policy on a continuing basis" 95 to reflect changing political, societal, and legal conditions. ${ }^{96}$ In so hold-

89 Id. at $865-66$.

90 Chevron's reasonableness inquiry plays virtually the same role as, and is often indistinguishable from, the arbitrary-and-capricious review of agency action taken pursuant to explicit congressional delegation. See, e.g., Smiley v. Citibank (S.D.), N.A., 517 U.S. 735, 742 (1996) (equating "arbitrary [or] capricious" with "disentitled to deference under Chevron"); Am. Wildlands v. Browner, 260 F.3d 1192, 1197 (10th Cir. 2001) (noting that in reviewing agency decisions under Chevron's step two, courts "review the agency action at issue ... under the arbitrary and capricious standard and, in conjunction, will ask only whether the [agency]'s interpretation of the Act implicit in its action is a permissible construction of the statute"); Chem. Waste Mgmt., Inc. v. EPA, 873 F.2d 1477, 1482 (D.C. Cir. 1989) (explaining that arbitrary-and-capricious claim is "functionally a Chevron step two contention that [the agency]'s interpretation of the statute is unreasonable"); Ronald $M$. Levin, The Anatomy of Chevron: Step Two Reconsidered, 72 Chi.-Kent L. Rev. 1253 (1997) (opining that Supreme Court's delegation model "strongly suggests that the second step of the Chevron formula was intended to be a direct counterpart to the arbitrariness test that courts had traditionally applied"). But see Cont'l Air Lines, Inc. v. Dep't of Transp., 843 F.2d 1444, 1452 (D.C. Cir. 1988) (arguing that while Chevron step two may be "closely akin to plain vanilla arbitrary-and-capricious style review," it would be inappropriate "to import wholesale that body of law and apply it in a conceptually distinct arena").

91 Mead, 533 U.S. at 229.

92 Smiley, 517 U.S. at 742.

93 Chevron, 467 U.S. at 840.

94 Id. at 863.

95 Id. at 863-64; see also Nat'l Cable \& Telecomms. Ass'n v. Gulf Power Co., 122 S. Ct. 782,788 (2002) ("Of course, the FCC has power to reconsider prior decisions."); Good Samaritan Hosp. v. Shalala, 508 U.S. 402, 417 (1993) (stating that agencies are not "disqualified from changing [their] mind" (quoting NLRB v. Local Union No. 103, Int'I Ass'n of Bridge, Structural \& Ornamental Iron Workers, 434 U.S. 335, 351 (1978))).

96 See Chevron, 467 U.S. at 865 (remarking that agency may consider policy options in light of "the incumbent administration's views of wise policy"); see also Jeffrey E. Shuren, 
ing, the Chevron court adopted the standard it had previously applied when Congress had explicitly charged agencies with interpretive authority - that agencies "must be given ample latitude to 'adapt [their] rules and policies to the demands of changing circumstances" 97 rather than the one that had governed the review of other administrative decisions-that an agency construction "in conflict with its initial position, is entitled to considerably less deference" 98 or no deference at all. ${ }^{99}$

Agencies possess similarly broad discretion as to the manner in which and rate at which they choose to reach their constructions of the statute, ${ }^{100}$ so long as those methods conform to their legislative delegation of authority. ${ }^{101}$ Building on pre-Chevron holdings barring courts from imposing additional burdens on agencies' exercise of explicitly delegated authority, ${ }^{102}$ the Supreme Court has confirmed that, as long as Congress has given it such power, an agency is free to choose whether to exercise either its rulemaking or its adjudicative authority; ${ }^{103}$ to resolve ambiguity piecemeal through an "evolutional"

The Modern Regulatory Administrative State: A Response to Changing Circumstances, 38 Harv. J. on Legis. 291, 292 (2001) ("[A]gencies are the governmental entities best equipped to respond to changing circumstances."). See generally Elena Kagan, Presidential Administration, 114 Harv. L. Rev. 2245 (2001) (documenting increased presidential control over administrative state).

97 Rust v. Sullivan, 500 U.S. 173, 187 (1991) (quoting Motor Vehicle Mfrs. Ass'n of United States, Inc. v. State Farm Mut. Auto. Ins. Co., 463 U.S. 29, 42 (1983) (quoting Permian Basin Area Rate Cases, 390 U.S. 747, 784 (1968))).

98 Watt v. Alaska, 451 U.S. 259, 273 (1981).

99 See, e.g., United Transp. Union v. Lewis, 711 F.2d 233, 242 (D.C. Cir. 1983) (asserting, in regards to agency that reversed its previous interpretation, that "[a] statutory construction to which an agency has not consistently adhered is owed no deference").

100 Certainly, the Court's decision in United States $v$. Mead Corp. set forth limits on an agency's ability to command judicial deference to constructions reached informally. See infra text accompanying notes 143-50. Yet that decision did not forbid an agency from acting in more informal ways. To the contrary, it specifically concluded that Congress had "in mind" that the agency would make informal rulings, Mead, 533 U.S. 218, 232 (2001), but that those rulings simply would not bind courts if challenged judicially.

101 See Chrysler Corp. v. Brown, 441 U.S. 281, 303 (1979) (explaining that promulgation of regulations must conform with procedural requirements imposed by Congress).

102 See, e.g., Vt. Yankee Nuclear Power Corp. v. Natural Res. Def. Council, Inc., 435 U.S. 519, 543 (1978) ("Absent constitutional constraints or extremely compelling circumstances the administrative agencies should be free to fashion their own rules of procedure and to pursue methods of inquiry capable of permitting them to discharge their multitudinous duties." (internal quotations omitted)).

103 See Am. Hosp. Ass'n v. NLRB, 499 U.S. 606, 612 (1991) (“[E]ven if a statutory scheme requires individualized determinations, the decisionmaker has the authority to rely on rulemaking to resolve certain issues of general applicability unless Congress clearly expresses an intent to withhold that authority."). 
approach; ${ }^{104}$ and even to refrain from filling statutory gaps until a later date. ${ }^{105}$

The scope of the discretion accorded agencies implicitly delegated interpretive authority indicates that, just as where Congress explicitly delegates authority, "the basic theory of Chevron ... is that agencies should be left free to make policy determinations where Congress has not."106

\section{II}

UNMOORING THE JUSTIFICATIONS FOR THE ADMINISTRATIVE State: Preserving Incorporation Theory After Chevron

\section{A. Post-Chevron Incorporation}

Despite Chevron's adjustment to the rule of judicial interpretive primacy, the Supreme Court has squarely rejected the argument that the rule of judicial precedent deserves parallel alteration when applied to agency interpretations of administrative statutes. Three times since Chevron-most recently in its unanimous decision in Neal v. United States ${ }^{107}$ - the Court instead has applied to the administrative law context the traditional standard of strong judicial precedent rooted in the theory of incorporation.

In the first two decisions, the Court held that Chevron's rulethat the judiciary must defer to reasonable agency constructions-did not apply when a court, before Chevron, had reached a different interpretation. In Maislin Industries, United States., Inc. v. Primary Steel, Inc. ${ }^{108}$ the Supreme Court considered the Interstate Commerce Commission's interpretation of a facially ambiguous provision in the Interstate Commerce Act. ${ }^{109}$ The Court rejected the agency's argument that its reasonable interpretation was entitled to deference under Chevron, on the ground that such an interpretation conflicted with a

104 See NLRB v. Curtin Matheson Scientific, Inc., 494 U.S. 775, 787 (1990) (reiterating rule of NLRB v. J. Weingarten, Inc., 420 U.S. 251, 265-66 (1975), that "[t] he use by an administrative agency of the evolutional approach is particularly fitting. To hold that the Board's earlier decisions froze the development of this important aspect of the national labor law would misconceive the nature of administrative decisionmaking").

105 See Nat'l Cable \& Telecomms. Ass'n v. Gulf Power Co., 122 S. Ct. 782, 788 (2002) ("Respondents are frustrated by the FCC's refusal to categorize Internet services [under the statute]. . . [D]ecisionmakers sometimes dodge hard questions when easier ones are dispositive; and we cannot fault the FCC for taking this approach.").

106 Michael Herz, Deference Running Riot: Separating Interpretation and Lawmaking Under Chevron, 6 Admin. L.J. Am. U. 187, 230 (1992), quoted in Bank of Am. v. FDIC, 244 F.3d 1309, 1321 (11th Cir. 2001).

107516 U.S. 284 (1996).

108497 U.S. 116 (1990).

109 ICC Termination Act of 1995 Act, Pub. L. No. 104-88, \& 102(a), 109 Stat. 803, 809 (codified as amended at 49 U.S.C. $\$ 10701$ (2001). 
policy that did not appear in the text of the Act but had been developed in long-standing Court precedent. The Court held that although the agency "has both the authority and expertise generally to adopt new policies when faced with new developments in the industry,"110 its interpretations must conform to "the Act, as it incorporates"111 the court-created doctrine. Pursuant to the theory of incorporation, the Court ruled that "[o]nce we have determined a statute's clear meaning, we adhere to that determination under the doctrine of stare decisis, and we judge an agency's later interpretation of the statute against our prior determination of the statute's meaning."112

Two years later, in Lechmere, Inc. v. $N L R B,{ }^{113}$ the Court reiterated this rule verbatim in rejecting the National Labor Relations Board's (NLRB's) test for determining when employers may preclude labor organizers from entering onto private property. ${ }^{114}$ The Court recognized that the Board's interpretations of ambiguous statutory provisions were entitled to deference. ${ }^{115}$ Yet it held that "[b]efore ... reach[ing] any issue of deference," it had to determine whether the NLRB policy was "consistent with [its] past interpretation of [the statute]."116 Finding that it was not, the Court disallowed the NLRB construction. ${ }^{117}$

Finally, in its unanimous opinion in Neal v. United States, ${ }^{118}$ the Court applied its incorporation rule to strike down an agency interpretation that conflicted with a post-Chevron precedent. Neal rejected an amendment to the United States Sentencing Guidelines regarding the method for calculating LSD weight, an amendment that the Court held conflicted with its own interpretation of the statutory language

110 Id. at 134.

111 Id. at 130 (emphasis added).

112 Id. at 131.

113502 U.S. 527 (1992).

114 Id. at $536-37$.

115 Id. at 536.

116 Id.

117 Id. at 539-41. Two dissenters proposed what I call the "provisional precedent" model. Justice White, joined by Justice Blackmun, urged the Court to apply straight deference principles. See id. at 541 (White, J., dissenting) ("[The NLRB's] application of the rule, if supported by substantial evidence on the record as a whole, must be enforced."). $\mathrm{He}$ argued that the Court precedent cited by the majority, NLRB v. Babcock \& Wilcox Co., 351 U.S. 105 (1956), was "at odds with modern concepts of deference to an administrative agency charged with administering a statute" because it did not ask whether the National Labor Relations Board (NLRB) construction of the statute was a permissible one, but instead "simply announced" its own rule. Lechmere, 502 U.S. at 545-46 (White, J., dissenting) (citing Chevron U.S.A., Inc. v. Natural Res. Def. Council, Inc., 467 U.S. 837, 837 (1984)).

118516 U.S. 284 (1996). 
set forth five years earlier in Chapman v. United States. ${ }^{119}$ The Court recognized that there was "little in logic" to defend Chapman's treatment of LSD but adhered to its former decision, confirming that when the Court has determined "a statute's meaning," later agency interpretations are assessed "against that settled law."120

As Justice Scalia has described, under the Supreme Court's incorporation rule, when a court provides a construction of a statutory term, the statute then "says what the court has prescribed," and it therefore becomes "unlawful" for an agency to take a contrary position. ${ }^{121}$ Thus statutory "ambiguity (and hence [agency] flexibility) ... cease with the first judicial resolution."122 "Statutory meaning," in Judge Kozinski's words,

is not a matter of hopes or wishes; it is a fact. In settling on a particular interpretation of a statute, the court is saying: "This is the meaning that was actually conferred upon this statute by Congress." ... A change in the agency's view ... may motivate a reviewing court to reconsider the soundness of its prior interpretation. But a change in an agency's position cannot automatically alter the meaning Congress gave the statute years earlier. ${ }^{123}$

Accordingly, the "fundamental principle of Constitutional law that the duty to interpret the statutes as set forth by Congress is a duty that rests with the judiciary ... [withholds from] any executive branch agency the power to overrule an established statutory construction of the court . ..."124 Judicial decisions, even after Chevron, are read in

119500 U.S. 453 (1991) (construing 21 U.S.C. $\$ 841(\mathrm{~b})(1)(B)(v)$ (current version at 21 U.S.C. $\$ 841(\mathrm{~b})(1)(\mathrm{B})(\mathrm{v})(2001)))$.

$120 \mathrm{Neal}, 516$ U.S. at 295.

121 United States v. Mead Corp., 533 U.S. 218, 247 (2001) (Scalia, J., dissenting).

122 Id.

123 Mesa Verde Constr. Co. v. N. Cal. Dist. Council of Laborers, 861 F.2d 1124, 1147 (9th Cir. 1988) (Kozinski, J., dissenting).

124 Bankers Trust N.Y. Corp. v. United States, 225 F.3d 1368, 1376 (Fed. Cir. 2000) (citing Marbury v. Madison, 5 U.S. (1 Cranch) 137, 177 (1803)); see Bob Evans Farms, Inc. v. NLRB, 163 F.3d 1012, 1017 (7th Cir. 1998) (questioning whether to give deference to NLRB interpretation that is contrary to judicial precedent since "resolving legal questions lies at the heart of the judicial function"); Indus. Turnaround Corp. v. NLRB, 115 F.3d 248, 254 (4th Cir. 1997) ("We are precluded from adopting [the NLRB's construction] . . . because it stands in conflict with ... a prior panel opinion of this court."); Aguirre v. INS, 79 F.3d 315, 317 (2d Cir. 1996) ("[Chevron] cannot compel a court to forgo the principle of stare decisis and abandon a construction previously made."); BPS Guard Servs., Inc. v. NLRB, 942 F.2d 519, 523 (8th Cir. 1991) ("Chevron does not stand for the proposition that administrative agencies may reject, with impunity, the controlling precedent of a superior judicial body."); see also Mesa Verde, 861 F.2d at 1145 (Hug, J., dissenting) ("In the name of administrative deference, the majority would deprive this court of its role of divining Congressional intent behind a statutory provision, and assign that role to the agency charged with administering the statute."). 
light of the "mechanical rule[]"125 that court precedents always trump Chevron deference.

\section{B. The Treatment of Precedent After Chevron:} The Threat to Constitutional and Normative Values

Since 1984, then, the Supreme Court has held that Congress generally invests agencies with responsibility for construing statutes and with broad discretion to reassess policy in light of changing circumstances. Yet the Court also has imported wholesale into its review of agency action the theory that judicial constructions are universally incorporated into statutory texts and that agencies lose their discretion to construe statutes once a court resolves the issue independently. By applying this pre-Chevron doctrine to cases that should be governed by Chevron's understandings about the relations between the branches of government, the Court has created a constitutional disconnect.

\section{Incorporation and Constitutional Legitimacy}

The Supreme Court has justified its "super-strong"126 adherence to statutory interpretation precedents with the very same constitutional doctrine-separation of powers-on which it premised Chevron deference. Specifically, the Court has explained, "[c]onsiderations of stare decisis have special force in the area of statutory interpretation," because in those cases "the legislative power is implicated, and Congress remains free to alter what we have done."127

Reflected in this formulation are two facets of separation-of-powers doctrine. One is a limit on the power of one's own branch: Courts are confined to the exercise of the judicial power, interpreting rather than making law. ${ }^{128}$ Indeed, the Court noted in Neal that it is specifi-

125 Pierce, supra note 24, at 2226; see Merrill \& Hickman, supra note 24, at 917 ("The Supreme Court's treatment of its own precedent is best understood as adopting . . . the blanket presumption that all past Supreme Court precedents are step-one precedents."); see also Alexander v. Sandoval, 532 U.S. 275, 281 n.1 (2001) (declaring principle of Lechmere and Maislin Industries, that pre-Chevron precedents do not need to be reconsidered, "settled").

126 See supra note 40 and accompanying text.

127 California v. FERC, 495 U.S. 490, 499 (1990) (quoting Patterson v. McLean Credit Union, 491 U.S. 164, 172-73 (1989)); see also Neal v. United States, 516 U.S. 284, 295 (1996) (applying strong stare decisis where "Congress is free to change this Court's interpretation of its legislation" (quoting Ill. Brick Co. v. Illinois, 431 U.S. 720, 736 (1977))).

128 See Anastasoff v. United States, 223 F.3d 898, 903 (8th Cir.), vacated as moot en banc, 235 F.3d 1054 (8th Cir. 2000) ("The duty of courts to follow their prior decisions was understood [in the late eighteenth century] to derive from the nature of the judicial power itself and to separate it from a dangerous union with the legislative power."); see also Patterson, 491 U.S. at 172 (asserting that the principle of stare decisis ensures "a jurispru- 
cally because courts - unlike Congress or agencies-can engage in law declaration, but not in policymaking, that the judiciary "do[es] not have the same latitude to forsake prior interpretations of a statute."129 The other limit is a required respect for the power of a co-ordinate branch. Thus, "Congress, not th[e] Court, has the responsibility for revising its statutes." 130

Yet the Court's application of incorporation theory to its postChevron review of agency action turns each purported constitutional interest-preventing courts from legislating and privileging the laws enacted by Congress-on its head. Far from preventing judges from engaging in lawmaking, the Neal rule enshrines judicial policy choices as binding positive law and removes discretion from the political executive branch. While Chevron places the discretion to construe statutory ambiguity outside the judicial ambit, the incorporation conception of precedent brings policymaking within it.

Similarly, in the guise of respect for Congress, the Court's precedent doctrine abrogates that body's intent, expressed either explicitly or implicitly. The Court protests that its rule simply allows the legislative branch to "revis[e] its statutes," or "correct statutes that are thought to be unwise or unfair" after they have been amended by judicial resolution of ambiguity or gap-filling. ${ }^{131}$ Yet rather than respecting Congress, the Court imposes on it a sort of "clear restatement rule," 132 by which Congress must re-enact the statutory intent that the Court has already clearly discerned, for "the agency (rather than the courts) to possess whatever degree of discretion the ambiguity allows."133

In sum, a rule of judicial precedent based on incorporation theory fails the requirement reflected in Article III: that "federal courts will make law only insofar as they are competent to do so and that in mak-

dential system that is not based upon an 'arbitrary discretion" " quoting The Federalist No. 78 , supra note 28 , bk. 2 , at 105$)$ ).

$129 \mathrm{Neal}, 516$ U.S. at 295.

130 Id. at 296.

$131 \mathrm{Id}$.

132 The Court has, in a number of contexts, required that Congress include in statutory text a "clear statement" of intent. Notably, the Court has imposed this heightened obligation when Congress seeks to abrogate state sovereignty. See Gregory v. Ashcroft, 501 U.S. 452, 461 (1991) (declining to find Missouri constitutional provision setting mandatory retirement age for appointed judges in violation of Federal Age Discrimination in Employment Act of 1967 absent "plain statement" of congressional intent to override state sovereignty). See generally Raygor v. Regents of Univ. of Minn., 122 S. Ct. 999, 1004-08 (2002) (summarizing case law). For an overview of the clear statement principle, see William N. Eskridge, Jr. \& Philip P. Frickey, Quasi-Constitutional Law: Clear Statement Rules as Constitutional Lawmaking, 45 Vand. L. Rev. 593 (1992).

133 Smiley v. Citibank (S.D.), N.A., 517 U.S. 735, 741 (1996). 
ing law they [must] not usurp the proper role of another branch of government."134

\section{When and Why Does It Matter?}

\section{a. Incorporation After Mead}

Scholars have downplayed the practical implications of the conflict between Chevron and stare decisis. ${ }^{135}$ For example, in their exhaustive assessment of the remaining "unanswered questions" as to Chevron's domain published shortly before the Supreme Court decided Mead, ${ }^{136}$ Thomas Merrill and Kristin Hickman minimize the number of cases in which an incorporation theory of precedent would preclude deference to agency interpretations. "More accurately considered," they assert, "the question of what to do about judicial precedent does not present an exception to Chevron, but illustrates the need for a transitional rule-a special rule of adjustment that medi-

134 Michael C. Dorf, Dicta and Article III, 142 U. Pa. L. Rev. 1997, 2001 (1994).

The Court is apparently becoming aware of the strange consequences of its incorporation rule, yet has dodged the doctrinal issue. This spring, in Edelman v. Lynchburg College, the Court considered a rule promulgated by the EEOC, and found it "not only ... reasonable ..., but the position we would adopt even if there were no formal rule and we were interpreting the statute from scratch." $122 \mathrm{~S}$. Ct. 1145, 1150 (2002). However, the Court shied away from declaring whether its holding was mandated by Chevron deference-in which case the agency could later adopt a different construction of the statuteor derived from a Skidmore analysis, in which case the agency could not. It stated only that, "[b]ecause we so clearly agree with the EEOC [Equal Employment Opportunity Commission], there is no occasion to defer and no point in asking what kind of deference, or how much." Id. at 1150. The doctrinal implications of that decision were muddled further by a footnote included at the end of this statement, noting: "We, of course, do not mean to say that the EEOC's position is the 'only one permissible." Id. at 1150 n.8. The footnote then suggests another possible interpretation. Id.

Justice O'Connor, concurring in the judgment on behalf of herself and Justice Scalia, expressed, consistent with the Court's jurisprudence, "doubt that it is possible to reserve th[e] question [of Chevron deference] while simultaneously maintaining, as the Court does, that the agency is free to change its interpretation." Id. at 1154 (O'Connor, J., concurring in judgment) (citation omitted). She suggested that the case fell squarely within the Chevron line, because "[t]o say that the matter is ambiguous enough to permit agency choice and to suggest that the Court would countenance a different choice is to say that the Court would (because it must) defer to a reasonable agency choice." Id.

Justice Souter, writing for the Court, rejected Justice O'Connor's suggestion "that recognizing [the existence of alternate interpretations] implies that a sphere of deference is appropriate, and so resolves the Chevron question." Id. at 1150 n.8. He noted instead, citing Mead, that "not all deference is deference under Chevron, and there is no need to resolve deference issues when there is no need for deference." Id. (citation omitted). However the majority did not address the fact that, had it determined that Skidmore, rather than Chevron, was the appropriate rubric of analysis, the incorporation doctrine would have bound future agency constructions.

135 See generally the discussion of scholarship, supra note 24 .

136 See Merrill \& Hickman, supra note 24, at 838. 
ates between the pre-Chevron and the post-Chevron worlds."137 They contend that in "a post-Chevron world in which all relevant decisions are taken in full awareness of Chevron's two-step procedure," courts will characterize their decisions either as Chevron "step-one" determinations of a statute's clear meaning, a determination that involves no administrative deference, and therefore should possess full precedential force, or as Chevron "step-two" decisions, holding only that an agency construction is "reasonable" or "unreasonable."138

To be sure, the Supreme Court first addressed precedent in the Chevron era by considering the binding nature of pre-Chevron decisions on later agency interpretations. Yet the number of decisions affected by its theory of judicial precedent is far greater than those Merrill and Hickman identify and, after last Term's Mead decision, ${ }^{139}$ the number of cases could expand exponentially.

Before Chevron, courts may or may not have based their interpretations of statutes on those provided by administrative agencies, or they may have been unclear as to their reasoning. But the "free substitution" of judicial constructions described by Judge Friendly ${ }^{140}$ did not end with Chevron. Even in the easy case in which an administrative interpretation is upheld under Chevron, courts do not always stop at a simple determination of reasonableness. Three years ago, in INS v. Aguirre-Aguirre ${ }^{141}$ the Supreme Court sustained the Board of Immigration Appeals's (BIA's) construction of the term "serious nonpolitical crime" as used in the section of the Immigration and $\mathrm{Na}$ tionality Act governing the deportation of those who have committed such offenses. ${ }^{142}$ The Court held it "clear" that Chevron was to provide the operative standard of review, ${ }^{143}$ found that "[a]s a matter of plain language" the statutory meaning was "not obvious,"144 and upheld the BIA's construction over a contrary one imposed by the Ninth Circuit. ${ }^{145}$ Yet the Court did not stop there; it also mentioned, by the

137 Id. at 917.

138 Id. at 916 . To this extent, the suggestions of Merrill and Hickman are harmonious with those set forth here. Yet they do not provide for a consistent result when a court does not utilize the Chevron framework, i.e., when a court interprets the statute before an agency utilizes any formal procedure for reaching an interpretation of its own.

139 See infra text accompanying notes 164-88.

140 Pittston Stevedoring Corp. v. Dellaventura, 544 F.2d 35, 49 (2d Cir. 1976), aff'd sub nom. Northeast Marine Terminal Co. v. Caputo, 432 U.S. 249 (1977).

141526 U.S. 415 (1999).

142 \& U.S.C. $\& 1253(\mathrm{~h})(2)(\mathrm{C})$ (2001).

143 Aguirre-Aguirre, 526 U.S. at 424.

144 Id. at 426.

145 Id. at 433. 
by, that the words of the statute "suggest" that the BIA's reading is "the more appropriate one." 146

This choice of language is particularly striking, for Chevron declared that once a court determines that Congress did not "actually have an intent" regarding the agency's construction of the statute, the "question before it" does not include "whether in its view the concept is "inappropriate." "147 Given this circumscription of the questionand presumably, therefore, the constitutional "case" or "controversy"-actually before the Aguirre-Aguirre Court, does the statute now "say[]" what the Court "prescribed?"148 Might the Court's decision mean, under an incorporation reading, that the preference for the BIA test has somehow been enshrined into law, or that the BIA could not adopt the Court of Appeals's construction down the line? It remains unclear. But, at a minimum, the existence of such surplus language in a Supreme Court opinion that so explicitly adopts Chevron's framework fifteen years after that case was decided suggests that the incorporation theory of precedent has the potential to siphon off administrative discretion even when the Court upholds the agency's decision.

Suppose, now, that the Court had not affirmed the BIA's test for determining whether a crime is serious and nonpolitical (holding instead that it was an unreasonable construction of the statute), but had adopted the Ninth Circuit's test instead.149 In so doing, the Court would have followed the advice of now-Justice Breyer, who, shortly after Chevron was decided, argued: "[I]f the agency has not offered a reasonable interpretation of the statute in this case; [or] if it has not considered the matter thoroughly [both grounds for rejection under Chevron's second step] then the court should simply decide the question on its own."150 Under the incorporation theory of precedent, despite the agency's affirmative conclusion that the matter at hand was important enough to warrant a formal administrative decision, a single interpretive error (or even one of process) permanently awards the policy choice to the judiciary. The agency, like an errant child, is sent to bed without discretion.

This last example indicates the principal category of cases in which congressionally delegated discretion may be diverted to the ju-

146 Id. at 426.

147 Chevron U.S.A., Inc. v. Natural Res. Def. Council, Inc., 467 U.S. 837, 845 (1984) (quoting Natural Res. Def. Council, Inc., 685 F.2d 718, 726 (D.C. Cir. 1982)).

148 United States v. Mead Corp., 533 U.S. 218, 247 (2001) (Scalia, J., dissenting).

149 Aguirre-Aguirre v. INS, 121 F.3d 521 (9th Cir. 1997).

150 Stephen Breyer, Judicial Review of Questions of Law and Policy, 38 Admin. L. Rev. 363, 379 (1986). 
diciary: those in which a court is presented with a question regarding a statute of which no agency has made an interpretation commanding deference. As discussed above, this happens when an agency has offered an interpretation that is not reasonable. But the same situation occurs more frequently for two other reasons: (1) because an agency has not yet interpreted a statute, or (2) because it has construed a statutory term in an informal manner that is not binding on courts. ${ }^{151}$

Courts have long heard Chevron cases in which an agency has not construed a statute before litigation. ${ }^{152}$ As an example, a Ninth Circuit panel recently reviewed a BIA decision denying asylum to an applicant. ${ }^{153}$ The applicant argued that the statute according asylum eligibility to members of certain "social group[s]" 154 should be interpreted to apply to members of "immediate famil[ies]" in which domestic violence occurs and thus should be applicable to her. ${ }^{155}$ The appeals court noted that "[ $\mathrm{t}]$ he BIA did not address the question whether a family can be a particular social group for asylum purposes" and concluded that Chevron was therefore "not relevant."156 It determined that it could "review de novo the legal question,"157 and it held that, because of her membership in an abusive family, "the petitioner is entitled to asylum protection as a member of a particular social group."158 Under the incorporation theory, if that decision stood, 159 proposed regulations on the subject currently being promulgated by the INS-even if they constituted a reasonable interpretation of the statute-would be invalid in the Ninth Circuit to the extent they differed from the court's rule. Such a result would govern, notwithstanding Chevron's instruction that, for an agency interpretation to be given effect, it need not be "the only one it permissibly could have adopted," or even "the reading the court would have reached if the question initially had arisen in a judicial proceeding."160

151 This was precisely the situation faced by the Court in Mead.

152 See, e.g., Bowen v. Georgetown Univ. Hosp., 488 U.S. 204, 212 (1988) (denying deference to agency litigating positions unsupported by preexisting regulations, rules, or agency practice).

153 Aguirre-Cervantes v. INS, 242 F.3d 1169 (9th Cir. 2001).

1548 U.S.C. $\$ 1101(\mathrm{a})(42)(\mathrm{A})$ (2001).

155 Aguirre-Cervantes, 242 F.3d at 1174.

156 Id.

$157 \mathrm{Id}$.

158 Id. at 1177.

159 For the moment, the panel opinion has been vacated pursuant to the stipulation of the parties and the matter remanded for further administrative proceedings. See AguirreCervantes v. INS, 273 F.3d 1220 (9th Cir. 2001).

160 Chevron U.S.A., Inc. v. Natural Res. Def. Council, Inc., 467 U.S. 837, 843 n.11 (1984). This seems much closer to the pre-Chevron regime, in which "questions of statutory interpretation, especially when arising in the first instance in judicial proceedings, are for the courts to resolve." NLRB v. Hearst Publ'ns, Inc., 322 U.S. 111, 130-31 (1944). 
The result required by incorporation in this type of case undermines the Supreme Court's claims that agencies possess great discretion on how and when to reach their decisions and how much to decide at any one time. For although an agency's discretion includes the power to take an "evolutional approach" to statutory construction, ${ }^{161}$ and although agencies may choose which matters of construction they wish to resolve, ${ }^{162}$ the legitimate exercise of lawful discretion becomes a means for permanent loss of that very discretion should a court decide the issue first. In such cases, vagaries of timing enduringly replace determinations of good policy.

The final situation in which a court is presented with no agency interpretation to which it must defer arises when an agency has construed the statute-however reasonably-in an informal manner that is not binding on courts. This was the very context in Mead, in which the Supreme Court vastly expanded this category of cases by limiting the types of agency interpretations that bind courts.

Mead held-consistent with Chevron's basis in legislative intent-that only those interpretations contained in a form Congress intended to have the "force of law," 163 such as formal rules or orders (commonly called "legislative rules"164), deserve judicial deference. ${ }^{165}$ By contrast, interpretations reached through less formal procedures (commonly called "interpretive rules"166) should be upheld-under the standard of Skidmore v. Swift \& Co.-only if they are "persua-

161 NLRB v. J. Weingarten, Inc., 420 U.S. 251, 265-66 (1975) (arguing that freezing policy "misconceive[s] the nature of administrative decisionmaking"); see also INS v. AguirreAguirre, 526 U.S. 415, 425 (1999) ("[T] he BIA should be accorded Chevron deference as it gives ambiguous statutory terms "concrete meaning through a process of case-by-case adjudication' . . ." (quoting INS v. Cardoza-Fonseca, 480 U.S. 421, 448 (1987))).

162 Nat'l Cable \& Telecomms. Ass'n, Inc. v. Gulf Power Co., 122 S. Ct. 782, 788 (2002).

163 United States v. Mead Corp., 533 U.S. 218, 227 (2001).

164 See Chrysler Corp. v. Brown, 441 U.S. 281, 302-03 \& nn.31-32 (1979) (contrasting "legislative" rules, which "have the force and effect of law," with "interpretive rules" and "general statements of policy," which do not) (internal citations omitted); see generally Richard J. Pierce, Jr., Distinguishing Legislative Rules from Interpretative Rules, 52 Admin. L. Rev. 547 (2000).

165 Mead concluded that Chevron deference is applicable when it is "apparent from the agency's generally conferred authority and other statutory circumstances that Congress would expect the agency to be able to speak with the force of law when it addresses ambiguity in the statute or fills a space in the enacted law." Mead, 533 U.S. at 229. The Court "recognized a very good indicator of delegation meriting Chevron treatment in express congressional authorizations to engage in the process of rulemaking or adjudication that produces regulations or rulings for which deference is claimed." Id. at 229; see also United States v. O'Hagan, 521 U.S. 642, 673 (1997) (according Chevron deference to agency given authority "to prescribe legislative rules").

166 See supra note 164. 
sive." 167 By far the majority of administrative choices are made by interpretive rather than legislative rulings ${ }^{168}$ and therefore must now be reviewed under Skidmore rather than Chevron. Because, under Skidmore, a court ultimately "interpret[s] the statute on its own,"169 applying the incorporation theory of precedent to interpretive rulings means that most judicial challenges to agency decisions will preclude the agency from ever adopting its own interpretation of a statute, even if it does so in a format that Congress has indicated must command judicial deference.

Appending the threat of a permanent loss of agency discretion to administration of a statutory scheme through interpretive rulings effects a perverse torsion in the notion of administrative deference. Supreme Court case law resoundingly avers that agency discretion includes an agency's right to choose, within the scope of the statutory delegation, the formality and timing of its decisions. The Court's rulings do not hold that agencies act improperly when they make decisions informally or do not act at all. ${ }^{170}$ Indeed, the case law indicates just the opposite; in Mead, for example, the Court mentioned specifically in the case of the Customs Service that Congress expressly had "in mind" that the majority of agency decisions would be made by interpretive rulings. ${ }^{171}$ Yet, in a judicial about-face, the incorporation approach transforms the agency's legitimate exercise of authority legally delegated by Congress into a means for that authority's elimination.

167 Quoting the Court's decision in Christensen v. Harris County, Mead rejected Chevron deference to a Customs Service "classification ruling," holding that it, like "interpretations contained in policy statements, agency manuals, and enforcement guidelines," fell "beyond the Chevron pale." Mead, 533 U.S. at 234 (quoting Christensen, 529 U.S. 576, $587(2000)$ ). The Court held, instead, that such interpretive rulings should be reviewed under the standard of Skidmore v. Swift, 323 U.S. 134 (1944), by which they are "eligible to claim respect according to [their] persuasiveness." Mead, 533 U.S. at 221.

168 See generally Peter L. Strauss et al., Gellhorn \& Byse's Administrative Law 384 (9th ed. 1995) (pointing out that "[a]n enormous part of what agencies do" does not comply with the formal requirements for legislative rulemaking). Agencies have incentives to use less formal rulemaking to prevent the policy "ossification" created by notice-and-comment rulemaking. See infra note 174 and accompanying text.

169 Mead, 533 U.S. at 248 (Scalia, J., dissenting) (emphasis omitted).

170 See supra notes 100-05 and accompanying text; see also Strauss et al., supra note 168, at 384-96 (detailing breadth of agency action not subject to formal process).

$171 \mathrm{Mead}, 533$ U.S. at 232. 


\section{b. Practical Implications-Mead's Incentive Structure and Incorporation's Threat to the Policies Underlying Administrative Policymaking}

The practical consequences of the transfer of discretion to the judiciary affected by the incorporation approach are tremendous. At a basic level, that transfer frustrates the very policy justifications for the administrative state articulated by the Supreme Court. Congress created administrative agencies with the understanding that they would be able to "adopt new policies when faced with new developments in the [regulated] industry"172 and thereby "adapt [their governing statutes] to changing patterns." 173 However, persisting with the incorporation approach after Mead "will lead to the ossification of large portions of our statutory law" 174 because "ambiguity (and hence flexibility) will cease with the first judicial resolution."175

More generally, the threat of losing discretion permanently creates perverse incentives towards administrative torpor and inaction.

172 Maislin Indus. v. Primary Steel, Inc., 497 U.S. 116, 134 (1990).

173 NLRB v. J. Weingarten, Inc., 420 U.S. 251, 266 (1975).

$174 \mathrm{Mead}, 533$ U.S. at 247 (Scalia, J., dissenting). This only adds to widespread concerns that ossification has resulted in the failure of the administrative state to govern efficiently and responsively. See, e.g., Richard J. Pierce, Seven Ways to Deossify Agency Rulemaking, 47 Admin. L. Rev. 59 (1995); Mark Seidenfeld, Demystifying Deossification: Rethinking Recent Proposals to Modify Judicial Review of Notice and Comment Rulemaking, 75 Tex. L. Rev. 483 (1997).

175 Mead, 533 U.S. at 247 (Scalia, J., dissenting). Justice Scalia raises this point as a criticism of the rule in Mead. However, it concisely identifies the practical problems of his own incorporation theory of precedent. Indeed, perhaps the best policy critique of incorporation's consequences appears in Justice Scalia's writings from over a decade ago, which criticize the pre-Chevron doctrine that granted less deference to "new" or "changing" agency interpretations:

Indeed, it seems to me that such an approach would deprive Chevron of one of its major advantages from the standpoint of governmental theory, which is to permit needed flexibility, and appropriate political participation, in the administrative process. One of the major disadvantages of having the courts resolve ambiguities is that they resolve them for ever and ever; only statutory amendment can produce a change. If the word "stationary source" in the Clean Air Act did not permit the "bubble concept" today, it would not permit the "bubble concept" four years from now either, no matter how much the perception of whether that concept impairs or furthers the objectives of the Act may change. Under Chevron, however, "stationary source" can mean a range of things, and it is up to the agency, in light of its advancing knowledge (and also, to be realistic about it, in light of the changing political pressures that it feels from Congress and from its various constituencies) to specify the correct meaning. If Congress is to delegate broadly, as modern times are thought to demand, it seems to me desirable that the delegee be able to suit its actions to the times, and that continuing political accountability be assured, through direct political pressures upon the Executive and through the indirect political pressure of congressional oversight.

Scalia, supra note 62 , at 517-18. 
Numerous commentators have demonstrated the increasingly burdensome process of rulemaking through notice-and-comment procedures.176 Mead, then, seems to offer a choice. When an agency believes that an issue is important enough that it wishes its policy choices to command deference in the courts, it must go through the more formal notice-and-comment rulemaking or adjudicative hoops necessary to create policy with the force of law. But agencies must make thousands of interpretive choices daily for our government to function, ${ }^{177}$ far more than could be-or should be-subject to formal procedure. Agencies therefore may reach these decisions through less formal means, recognizing that they deserve no deference and will be overturned if a judge does not find them persuasive. ${ }^{178}$

Conditioning the ability to make decisions quickly on the possibility of permanently losing future decisionmaking authority, if those decisions are challenged, places too great a cost on the decision to make interpretive rules. An agency concerned with preserving its discretion faces two alternatives: (1) inaction (if it believes that the absence of a policy will prevent a court challenge), or (2) more formal but time-consuming Chevron-triggering procedures. ${ }^{179}$

176 See, e.g., Thomas O. McGarity, Some Thoughts on "Deossifying" the Rulemaking Process, 41 Duke L.J. 1385, 1385-86 (1992) ("[T]he rulemaking process has become increasingly rigid and burdensome. ... [M] any observers from across the political spectrum agree ... that it is one of the most serious problems currently facing regulatory agencies.").

177 See generally Robert A. Anthony, Interpretive Rules, Policy Statements, Guidances, Manuals and the Like-Should Federal Agencies Use Them to Bind the Public?, 41 Duke L.J. 1311 (1992) (detailing agency use of nonlegislative rules and arguing that such rules should not be binding on public unless they interpret specific statutory language).

178 This choice is clearly illustrated by the statutory structure of the Customs Service, whose classification ruling was at issue in Mead. Customs issues ten to fifteen thousand classifications rulings yearly. See Mead, 533 U.S. at 233 . It would be both impossible and a poor use of resources to make such rulings through formal procedures by means of "legislative rules." Few rulings would be issued and imports to the United States would not be processed. Thus, the rulings are reached through more informal processes. The Mead Court indicated that the use of such interpretive rules was legitimate; indeed, in this instance Congress had such forms of decisionmaking "in mind" when it authorized Customs to issue regulations. Mead, 533 U.S. at 232. The rulings, however, do not deserve Chevron deference.

Yet Congress also delegated to Customs the power to issue regulations with the force of law. When Customs decides that the policy at issue is important enough to merit judicial deference, the agency meets notice-and-comment requirements, ensuring that its reasonable regulations will be upheld. See, e.g., United States v. Haggar Apparel Co., 526 U.S. 380 (1999) (deferring to Customs's regulation under Chevron).

179 The fact that Customs, for one, will have to continue using the classification ruling process to function under incorporation theory leads to a nonsensical regime. The judiciary can determine policy as to the most fact-specific cases, such as whether the Mead Corporation's spiral-bound date books may enter the United States duty free (the question in Mead). See Mead, 533 U.S. at 224-25. But the agency retains discretion over more legislative rules, such as the definition of "operations incidental to the assembly process" of permapressed pants (the issue in Haggar Apparel). See Haggar Apparel, 526 U.S. at 386. 
Finally, the incorporation approach's transfer of discretion to the judiciary inappropriately injects randomness into national policymaking. On the most basic_-and most troubling - level, the timing of judicial challenges becomes a significant factor determining policy; vagaries replace values.

Beyond the fact that this seems a generally unwise way to administer government agencies, the desultory effects of incorporation theory create incoherence in the application of national policy, a result anathemic to both the values underlying precedent, such as reliability and uniformity in legal rules, and those behind deference to administrative choices. ${ }^{180}$ Although the policy justifications for committing discretion to administrative expertise are strongest when the agency must rationalize policy throughout a complex statutory scheme, an incorporation theory of precedent means that subsidiary issues which, as fate would have it, were decided previously in court cases, remain stagnant as broader policy progresses. ${ }^{181}$ Similarly, on the court of appeals level, the development of binding precedent in one court ensures that that court "will be frozen on certain interpretations" as agency policy develops "whereas other circuits would not, depending on the random occurrence of cases within the circuits."182 Such disharmony fosters circuit splits across the substantive range of regulatory policy, ${ }^{183}$ defeating one of the primary benefits of Chevron's

180 See, e.g., Patterson v. McLean Credit Union, 491 U.S. 164, 173 (1989) (finding that "traditional justification" for disregarding precedent is that it is "a positive detriment to coherence and consistency in the law ... because the decision poses a direct obstacle to the realization of important objectives embodied in other laws").

181 Compare Indus. Turnaround Corp. v. NLRB, 115 F.3d 248, 254 (4th Cir. 1997) (rejecting portion of NLRB's analytical framework as precluded by precedent), with Am. Automatic Sprinkler Sys., Inc. v. NLRB, 163 F.3d 209, 215-16 (4th Cir. 1998) (adopting different portion of that framework).

182 Mesa Verde Constr. Co. v. N. Cal. Dist. Council of Laborers, 861 F.2d 1124, 1136 (9th Cir. 1988) (en banc).

183 For example, in the labor context, the Fourth Circuit, relying on circuit precedent, has split with seven other circuits in rejecting one new NLRB construction. Compare Indus. Turnaround, 115 F.3d at 254 ("We are precluded from adopting [the NLRB's construction] as the law of the Circuit because it stands in conflict with . . . a prior panel opinion of this court."), with NLRB v. Triple A Fire Prot., Inc., 136 F.3d 727, 735 (11th Cir. 1998) (deferring to agency's construction), NLRB v. Viola Indus.-Elevator Div., Inc., 979 F.2d 1384, 1393-95 (10th Cir. 1992) (en banc) (same), C.E.K. Indus. Mech. Contractors, Inc. v. NLRB, 921 F.2d 350, 357 (1st Cir. 1990) (same), NLRB v. Bufco Corp., 899 F.2d $608,609,611$ (7th Cir. 1990) (same), NLRB v. W.L. Miller Co., 871 F.2d 745, 748 (8th Cir. 1989) (same), Mesa Verde Constr. Co., 861 F.2d at 1129-34 (same), and Int'l Ass'n of Bridge, Structural \& Ornamental Iron Workers v. NLRB, 843 F.2d 770, 779-80 (3d Cir. 1988) (same). The Ninth and Seventh Circuits have split on whether to give effect to another NLRB construction. Compare United Food and Commercial Workers Union, Local 1036 v. NLRB, 249 F.3d 1115, 1119 (9th Cir. 2001) (rejecting NLRB construction because "the Board does not have a free hand to interpret a statute when the Supreme Court has 
regime: If "courts in Maine, Florida and California each believe that, absent clear statutory resolution of an issue, it must accept the [agency]'s 'reasonable' judgments about statutory meaning [it is] more likely that the statute will have the same effective meaning in each circuit."184 Meaningful application of policy is skewed further because the venue provisions contained in many administrative statutes often allow review of a single case in any of several, or even all, of the circuit courts. ${ }^{185}$ As the former Solicitor of the Federal Labor Relations Authority has argued, "[t]he interest in a national, uniformly administered ... program is undercut by the potential [that] the party aggrieved by the [agency]'s decision will inevitably prevail through judicial forum shopping."186

already interpreted the statute"), with Int'l Ass'n of Machinists v. NLRB, 133 F.3d 1012, 1019 (7th Cir. 1998) (deferring to agency construction).

For examples in the tax context, compare Bankers Trust N.Y. Corp. v. United States, 225 F.3d 1368, 1376 (Fed. Cir. 2000) (striking down application of Treasury regulation in light of circuit precedent because "an Executive agency regulation [may not] effectively construe a statute in a manner different from a prior definitive court ruling [and t] Chevron doctrine, properly understood, does not change this basic application of Separation of Powers doctrine"), with Norwest Corp. v. Comm'r, 69 F.3d 1404, 1408-09 (8th Cir. 1995) (deferring to Treasury regulation), and Cont'l Ill. Corp. v. Comm'r, 998 F.2d 513, 520 (7th Cir. 1993) (same). In the context of the Federal Sentencing Guidelines, compare United States v. Palacio, 4 F.3d 150, 154 (2d Cir. 1993) (refusing to modify interpretation of Guidelines because "[e]ven if the Commission's pending view of the [Guidelines term] might have influenced us ... as an original matter, once we have construed the statute, we will not reinterpret it in the absence of new guidance from Congress"), with United States v. Barbosa, 271 F.3d 438, 465 (3d Cir. 2001) (reviewing change with understanding that "we are [not] constrained by stare decisis in the same way as were the Second Circuit in Palacio and the Supreme Court in Neal"), and United States v. Munoz-Realpe, 21 F.3d 375, 377 (11th Cir. 1994) (applying revised interpretation).

184 Peter L. Strauss, One Hundred Fifty Cases Per Year: Some Implications of the Supreme Court's Limited Resources for Judicial Review of Agency Action, 87 Colum. L. Rev. 1093, 1122 (1987). In Strauss's words: “[J]udges are more likely to reach agreement in identifying a range of indeterminacy that Congress did in fact create, than they are in searching ... for a specific answer ...." Id.

185 See, e.g., 29 U.S.C. $\$ 160$ (e) (2001) (allowing National Labor Relations Board to petition any court of appeals in circuit in which unfair labor practice took place or in which person engaging in such practice resides or transacts business); 5 U.S.C. $\$ 7123$ (2001) (allowing judicial review of Federal Labor Relations Authority order in D.C. Court of Appeals or in court of appeals of circuit in which aggrieved person either resides or conducts business). See generally Arvin Automotive, 285 N.L.R.B. 753, 757 (1987) ("It is thus apparent that we operate under a statute that simply does not contemplate that the law of a single circuit would exclusively apply in any given case."). But see, e.g., 42 U.S.C. $\$ 6976$ (a)(1) (2001) (giving D.C. Circuit exclusive jurisdiction over petitions for review of all Resource Conservation and Recovery Act rules issued by Environmental Protection Agency); 47 U.S.C. $\$ 402$ (b) (2001) (placing jurisdiction for suits challenging certain classes of Federal Communication Commission decisions in D.C. Circuit).

186 Letter from David M. Smith, Solicitor of the Federal Labor Relations Authority, to Bert M. Montague, Clerk, United States Court of Appeals for the Fourth Circuit (Oct. 2, 1996), reprinted in United States Dep't of Energy v. Fed. Labor Relations Auth., 106 F.3d 1158, 1167-68 (4th Cir. 1997), abrogated by Nat'l Fed'n of Fed. Employees, Local 1309 v. 
In practice, the opportunity for Supreme Court review of court of appeals decisions is severely limited, and the occasion for congressional "overturning" of judicial precedents is even more infrequent. ${ }^{187}$ Thus, the continued application of the incorporation theory of judicial precedent after Mead will increasingly render widespread denial of administrative discretion permanent. This development threatens the tragedy foreseen by Justice Frankfurter, that if a court may "write [its own] principle[s] ... into the statute as an indirect result of its power to scrutinize legal errors in the first of an allowable series of administrative actions," then for "practical purposes the contingencies of judicial review and of litigation, rather than the public interest, would be decisive factors in determining" policy. ${ }^{188}$

\section{IV}

A Theory of Provisional Precedent

For the Judicial Review of Administrative Action

In light of this reality, the question is how to reconcile the presumptive congressional intent that agencies be allowed to decide ambiguity "first and foremost"189 - i.e., that they should be able to choose when and how they make policy, and to remain free to alter their policies according to expert administrative policy assessments, executive branch policy preferences, and other changing circumstances-with the reality that courts often must resolve disputes involving statutory provisions regarding which they are not required, nor do they have the opportunity, to defer to agency views. If precedent by incorporation does not provide a coherent accommodation, what is the alternative?

\section{A. The Federalism Model}

The alternative need not arise from a clean slate, for a model already exists for accommodating these concerns: the doctrines governing federal court adjudication of state law. The resolution of cases and controversies before federal courts often rests on state law,

Dep't of the Interior, 526 U.S. 86 (1999). A similar argument arises in the debate over agency "nonacquiescence" to circuit court precedent. See Samuel Estreicher \& Richard L. Revesz, Nonacquiescence by Federal Administrative Agencies, 98 Yale L.J. 679, 709-10 (1989) (explaining that due to breadth of venue choice, National Labor Relations Board does not always know which court of appeals will hear case).

187 The two points are related. While the approximately six Supreme Court cases per year that Congress has overturned, see Bob Cohn, Supreme But Not Final, Newsweek, Oct. 12,1992, at 78, may seem sizable when compared to the total number of high court decisions, the number pales in light of the total number of federal court decisions.

188 FCC v. Pottsville Broad. Co., 309 U.S. 134, 145-46 (1940).

189 Smiley v. Citibank (S.D.), N.A., 517 U.S. 735, 740-41 (1996). 
whether positive law or rules of decision. The primary authority for making and construing that law falls under state jurisdiction; ${ }^{190}$ federal courts are only supreme in determining the limits of state power set by the United States Constitution and other federal laws. Yet the state law nature of the question in itself does not "afford a sufficient ground for a federal court to decline to exercise its jurisdiction to decide a case which is properly brought to it for decision."191 Therefore, federal courts frequently must apply state rules in new contexts that necessitate resolution of ambiguities unaddressed or unforeseen by state courts or legislatures.

This dilemma is resolved in two ways. In very limited circumstances, federal courts possess the discretion to refrain from acting until state courts have settled the state law issue, either by abstaining until state adjudication resolves the open state question, ${ }^{192}$ or-where the relevant state's law permits-by certifying the question to the state's highest tribunal. ${ }^{193}$

190 See R.R. Comm'n v. Pullman Co., 312 U.S. 496, 499-500 (1941) ("The last word on the meaning of [Texas state law] ... belongs neither to us nor to the district court but to the supreme court of Texas."); Erie R.R. Co. v. Tompkins, 304 U.S. 64, 78 (1938) ("Congress has no power to declare substantive rules of common law applicable in a State .... And no clause in the Constitution purports to confer such a power upon the federal courts.").

191 Meredith v. Winter Haven, 320 U.S. 228, 234 (1943). See Federal Rules of Decision Act, 28 U.S.C. $\$ 1652$ (2001) ("The laws of the several states, except where the Constitution or treaties of the United States or Acts of Congress otherwise require or provide, shall be regarded as rules of decision in civil actions in the courts of the United States, in cases where they apply."); see also, e.g., United Mine Workers v. Gibbs, 383 U.S. 715 (1966) (holding that federal courts exercising federal question jurisdiction also may decide statelaw questions under pendent jurisdiction); Erie, 304 U.S. at 78-80 (ruling that federal courts must apply state law in diversity jurisdiction cases).

192 See, e.g., La. Power \& Light Co. v. City of Thibodaux, 360 U.S. 25, 29 (1959) (abstaining because uncertain state law involves "a matter close to the political interests of a State"); Burford v. Sun Oil Co., 319 U.S. 315, 334 (1943) (abstaining because federal determination would disrupt complex state regulatory schemes in situations where aggrieved parties were provided with "expeditious and adequate" state review); Pullman Co., 312 U.S. at 496 (holding that abstention is appropriate when uncertain question of state law may be decided in way that would eliminate need to address federal constitutional issue or affect analysis of that issue). While abstaining, federal courts hold the case in abeyance, retain jurisdiction, and direct the parties to proceed through state channels, usually by seeking a declaratory judgment from the state court on the open state-law issue. See generally Richard H. Fallon, Jr., et al., Hart and Wechsler's the Federal Courts and the Federal System 1230-56 (4th ed. 1996) (providing thorough discussion of abstention doctrine).

193 Forty-five state high courts are empowered to accept interjurisdictional certified questions of state law. See Judith S. Kaye \& Kenneth I. Weissman, Interactive Judicial Federalism: Certified Questions in New York, 69 Fordham L. Rev. 373 app. A at 422 (2000) (listing state certification laws). Arkansas, New Jersey, North Carolina, and Vermont have not adopted certification procedures, and Missouri's statute has been held unconstitutional by that state's supreme court. See id. at 373 \& n.1 (citing Grantham v. Mo. Dep't of Corr., No. 72576, 1990 WL 602159, at *1 (Mo. July 13, 1990)). 
Yet in nearly every instance in which a federal court is faced with an open state law question, it decides it. Those decisions are clearly authoritative for the parties to the case ${ }^{194}$ and have "binding precedential effect" on other federal courts, "absent a subsequent state court decision or [legislative] amendment" adopting a contrary construction. ${ }^{195}$ But once a state exercises its primary authority to make such a decision or amendment, the federal interpretation is no longer binding. ${ }^{196}$ Its precedential value is, literally, provisional.

\section{B. Applying the Federalism Model to the Separation-of-Powers Context}

Certainly, the federalism concerns structuring the relation between federal courts and state actors do not govern the administrative law context. Yet the model of federal adjudication of state law issues provides a functional framework for reconciling the doctrinal conflicts raised by judicial interpretation of administrative statutes, and for preserving flexibility in policymaking. ${ }^{197}$

194 See, e.g., McGeshick v. Choucair, 72 F.3d 62, 64-65 (7th Cir. 1995) (declaring that even subsequent adoption by state courts of construction of state law contrary to that on which federal court decision was based does not provide grounds for parties' relief from judgment); DeWeerth v. Baldinger, 38 F.3d 1266, 1273-74 (2d Cir. 1994) (same).

195 Ford v. Cimarron Ins. Co., 230 F.3d 828, 832 (5th Cir. 2000). As a rule, even the Supreme Court generally "follows lower federal-court interpretations of state law." Stenberg v. Carhart, 530 U.S. 914, 940 (2000).

196 See, e.g., McGeshick, 72 F.3d at 64 ("The very nature of diversity jurisdiction leaves open the possibility that a state court will subsequently disagree with a federal court's interpretation of state law." (quoting DeWeerth, 38 F.3d at 1273-74)); see also Leavitt v. Jane L., 518 U.S. 137, 146 (1996) (Stevens, J., dissenting) ("[T]he decision of a federal court (even this Court) on a question of state law is not binding on state tribunals ...."); Moore v. Sims, 442 U.S. 415, 428 (1979) (stating that when federal court making constitutional determination about state law is "forced to interpret state law without the benefit of statecourt consideration," it does so "under circumstances where [that] constitutional determination is predicated on a reading of the statute that is not binding on state courts and may be discredited at any time").

197 Professor Monaghan's scholarship on judicial "boundary-setting" in constitutional adjudication suggests a different analog: judicial constitutional review of legislative action. This approach may be more fitting doctrinally (as it rests in separation-of-powers principles), but it may be less instructive in providing a parallel detailed framework for adjudication. See Henry P. Monaghan, Marbury and the Administrative State, 83 Colum. L. Rev. 1,33 (1983) (noting similarity between judicial review in administrative and constitutional law in that in both " $[\mathrm{t}]$ he Court ... simply determines whether Congress has exceeded the outer boundaries of a very wide domain for choice"). For a parallel between the administrative and state-law realms, see Philip J. Weiser, Federal Common Law, Cooperative Federalism, and the Enforcement of the Telecom Act, 76 N.Y.U. L. Rev. 1692, 1715-18 (2001) (analogizing Chevron's limit on judicially made federal common law to that effected by Erie R.R. v. Tompkins, 304 U.S. 64, 74-79 (1938)). 


\section{Abstention}

Federal courts already have, in certain circumstances, limited discretion to abstain from deciding in the first instance matters delegated to agencies. The Supreme Court recently confirmed the vitality of the traditional doctrine of "primary jurisdiction,"198 though it has not applied the doctrine since before the Chevron decision. Under primary jurisdiction, specific issues of the type usually resolved in agency adjudication (like the setting of rates) "might ... [be] referred, prior to any court's consideration, to the [agency]." 199 Moreover, when courts find flaws in the manner used to reach an initial interpretation, they often remand the matter to an agency rather than decide it outright. 200

Yet the widespread use of a judicial "abstention" doctrine in the administrative law context raises significant problems. First, it would in many instances impose great costs. ${ }^{201}$ While the delay and expense of requiring an individual litigant to engage in informal administrative adjudication before obtaining federal court resolution might be justifiable, those costs would be magnified if the statutory ambiguity before a court is resolved on remand through notice-and-comment rulemaking (an even more likely scenario after $M e a d$ ), requiring the involve-

198 Northwest Airlines, Inc. v. County of Kent, 510 U.S. 355, 366 n.10 (1994) (observing that question of whether Airport's rates were reasonable under Anti-Head Tax Act "might have been referred ... to the Department of Transportation under the primary jurisdiction doctrine," but declining to do so because "the parties have not briefed or argued this question"); Reiter v. Cooper, 507 U.S. 258, 268-69 (1993) (describing doctrine and citing preChevron cases).

199 Northwest Airlines, 510 U.S. at 366 n.10 (1994).

200 In National Federation of Federal Employees, Local 1309 v. Department of the Interior, for example, the Supreme Court held under Chevron's step one that the statutory "language [was] sufficiently ambiguous or open on the point as to require judicial deference," 526 U.S. 86, 92 (1999), but it declined to defer to the agency's revised interpretation because that interpretation appeared to have been occasioned only by an erroneous D.C. Circuit decision, rather than "an independently reasoned effort to develop complex labor policies." Id. at 100. Instead of reaching an interpretation of its own, the Court remanded because "the Authority should have the opportunity to consider these questions aware that the Statute permits, but does not compel, the conclusions it reached." Id. See generally William S. Jordan, III, Judges, Ideology, and Policy in the Administrative State: Lessons from a Decade of Hard Look Remands of EPA Rules 53 Admin. L. Rev. 45 (2001) (discussing D.C. Circuit remands of Environmental Protection Agency (EPA) rules from 1985 to 1995).

201 See, e.g., Arizonans for Official English v. Arizona, 520 U.S. 43, 76 (1997) ("Attractive in theory because it placed state-law questions in courts equipped to rule authoritatively on them, Pullman abstention proved protracted and expensive in practice, for it entailed a full round of litigation in the state court system before any resumption of proceedings in federal court."); England v. La. State Bd. of Med. Exam'rs, 375 U.S. 411, 418 (1964) (commenting on "delay and expense to which application of the abstention doctrine inevitably gives rise"); cf. Hardin v. Straub, 490 U.S. 536, 543 n.10 (1989) (noting "federal interest in disposing of all litigation in the federal courts as expeditiously as possible"). 
ment of-and creating uncertainty for-all parties affected by the regulatory proceeding. ${ }^{202}$

Even more serious, applying a widespread administrative abstention doctrine would both create perverse incentives for agency inaction and cause significant unfairness to parties adverse to the agencies in litigation. The agency would not need to make a considered judgment on statutory construction during the normal course of policymaking to ensure that it would prevail in any particular case; it always would be given the chance to reach a deference-deserving interpretation before litigation was concluded. The problems caused by such an unfair litigation advantage are reflected by Supreme Court case law rejecting agency constructions made for the first time in a litigation brief. $^{203}$

\section{A Rule of Provisional Precedent}

If abstention seems as ill-suited to extensive application in administrative law cases as it does in the federalism context, a theory of provisional precedent appears to be as appropriate. Under such a theory, where courts resolved statutory interpretation questions on which "[t]he judiciary is the final authority"-those involving the discernment of "clear congressional intent"204_the ordinary doctrine of binding precedent would apply. This category of holdings includes Chevron step one conclusions regarding a statute's plain meaning; identifications of the limits of statutory ambiguity (and therefore agency discretion) under Chevron's step two; 205 and holdings of any other sort, such as those under Skidmore or under an analysis that accords no deference whatsoever, that a statute allows only one construction.

When, however, Congress intended "the agency (rather than the courts) to possess whatever degree of discretion the ambiguity allows"

202 Indeed, unless the primary jurisdiction doctrine were expanded to include some mechanism to ensure action by recalcitrant agencies on remand, there is no assurance of timely agency decisionmaking-or any decisionmaking at all-in one category of cases: those in which the regulatory agency never before found the need to make an interpretation of the ambiguous statutory provision and is not a party to the judicial action. These were the circumstances in Northwest Airlines, 510 U.S. at 367.

203 See, e.g., Bowen v. Georgetown Univ. Hosp., 488 U.S. 204, 213-14 (1988) (denying deference to agency litigating positions unsupported by preexisting regulations, rules, or agency practice).

204 Chevron U.S.A., Inc. v. Natural Res. Def. Council, Inc., 467 U.S. 837, 843 n.9 (1984).

205 Professor Ronald Levin cleverly calls these step two reversals instances of "belatedly discovered clear meaning" because they occur after the determination, in step one, that the statute is ambiguous, but involve the court finding that, however vague the statute was, it clearly means something different than the agency's interpretation. See Levin, supra note 90 , at $1282-83$. 
(i.e., whenever "it le[aves] ambiguity in a statute meant for implementation by an agency"), ${ }^{206}$ a judicial choice of one option within the zone of indeterminacy, although it would be authoritative in resolving the case or controversy, would constitute binding precedent only until an agency puts forth a different one in a manner deserving Chevron treatment. A rule of provisional precedent in the administrative law context would conserve the ability of agencies to exercise the primary interpretive authority delegated to them by Congress, prevent policy from being removed from the hands of expert administrators and frozen despite changing circumstances, and ensure that future courts could, unobstructed, give straightforward effect to Chevron's requirement that the judiciary must defer to reasonable administrative constructions. More specifically, such a rule would allow agencies the choice suggested by Mead (i.e., either to go through the long process of making formal policy, knowing that it will command judicial deference, or to reach day-to-day decisions more informally while sacrificing controlling weight) without the threat of losing discretion in perpetuity, severely tilting the scale towards formal process. ${ }^{207}$

\section{a. Grocery Manufacturers of America, Inc. v. Gerace: The Road Not Taken}

Curiously, the year after Chevron was decided and several years before Maislin Industries, in its first post-Chevron incorporation-theory decision, the Supreme Court took a step in the direction of a provisional precedent approach in a summary affirmance ${ }^{208}$ that has never since been cited, either in the Court's opinions or in the scholarly literature. ${ }^{209}$ That case, Grocery Manufacturers of America, Inc. v. Gerace, ${ }^{210}$ involved a challenge to a portion of New York State's

206 Smiley v. Citibank (S.D.), N.A., 517 U.S. 735, 740-41 (1996).

207 See, e.g., Doe v. Mut. of Omaha Ins. Co., 179 F.3d 557, 563 (7th Cir. 1999) (refusing to defer to agency position set forth in form that "cannot claim much democratic legitimacy to set over against the intent of Congress" and stating that agency had made "sufficiently far-reaching interpretive stride to justify us in requiring the Department to invite deference by a more deliberative, public, and systematic procedure").

20 See Edelman v. Jordan, 415 U.S. 651, 671 (1974) (stating that "[s]ummary affirmances obviously are of precedential value" but "[e]qually obviously, they are not of the same precedential value as would be an opinion of this Court treating the question on the merits," similar to context of constitutional question when court is "less constrained by the principle of stare decisis than we are in other areas of the law").

209 The Second Circuit cited the underlying case, Grocery Manufacturers of America, Inc. v. Gerace, 755 F.2d 993 (2d Cir. 1985), in an opinion holding that an agency that was explicitly delegated interpretive authority could adopt a rule at variance with one previously adopted in circuit precedent. See Schisler v. Sullivan, 3 F.3d 563, 568 (2d Cir. 1993) ("[T]he fact that differences may exist between the new regulations and our version of the treating physician rule does not invalidate the regulations.").

210755 F.2d 993 (2d Cir.), aff'd 474 U.S. 801 (1985) (mem.). 
agricultural goods labeling law that required cheese products containing some cheese "alternatives" to be labeled as "imitation" cheese. 211 The plaintiff contended that the state law was preempted by the contrary definition set forth in federal food and drug regulations. ${ }^{212} \mathrm{New}$ York State (the defendant), in turn, challenged the validity of the federal regulation on the ground that the Food and Drug Administration's (FDA's) definition of "imitation" conflicted with the Supreme Court's earlier constructions of the statutory term. ${ }^{213}$

The Second Circuit recognized that "the FDA's regulatory definition of imitation is at odds with the judicial gloss placed on the term."214 The court, however, decided that "the earlier and undeniably reasonable judicial construction of imitation did not 'prevent the promulgation of an equally reasonable definition by the agency charged with administering the [statute]." "215 Therefore, "our deference to the enforcing agency's interpretation limits our review to determining only whether the regulation violates the language of the statute or is arbitrary and capricious." 216 The court thus deferred to the FDA's construction and deemed the state statute preempted;217 eight months later, the judgment was affirmed summarily by the Supreme Court. 218

Although the Supreme Court did not take the opportunity to add its own commentary to the decision, the affirmance necessarily rested on the proposition that the agency's reasonable statutory construction trumped preexisting Supreme Court interpretations; if it did not, the FDA regulation would not have been valid, and the state statute would not have been in conflict with governing federal law. In Chevron's immediate wake, then, at least seven Justices (Justices Rehnquist and O'Connor would have noted probable jurisdiction and set the case for oral argument ${ }^{219}$ ) were open to the principle that judi-

211 See id. at 996-97 (describing 63 N.Y. Agric. \& Mkts. McKinney 1991).

212 Under the federal regulations, a product was an "imitation" only if it was, among other things, "nutritionally inferior" to the food for which it was substituting. Neither party disputed the nutritional equivalence of the cheese alternative; therefore, it would be misbranded under federal law if it were labeled as required by state statute. See id. at $997-$ 98 (quoting 21 C.F.R. $\S 101.3(\mathrm{e})(1)$ (2002)).

213 Grocery Mfrs., 755 F.2d at 999 . In the principal precedential case, 62 Cases of Jam $v$. United States, the Court ruled that, under the statute, products that failed to meet the Food and Drug Administration requirements for jam could be labeled "imitation" jam if they "look[ed] and taste[d]" like the original. 340 U.S. 593, 599 (1951).

214 Grocery Mfrs., 755 F.2d at 1000.

215 Id. at 1001 (quoting Fed'n of Homemakers v. Schmidt, 539 F.2d 740, 743 (D.C. Cir. 1976)).

216 Id. (quoting Fed'n of Homemakers, 539 F.2d at 743).

217 Id.

218 See Gerace v. Grocery Mfrs., 474 U.S. 801 (1985) (mem.).

219 See id. at 801 . 
cial constructions of ambiguous statutory terms constitute "judicial gloss[es]," 220 which may be set aside by later reasonable agency constructions. 221

\section{b. Mapping the Road Not Taken: The Implications of a Provisional Precedent Theory for Interpreting and Deciding Cases}

A theory of provisional stare decisis presents ramifications both for reading precedents and for making them. For courts interpreting past judicial holdings, the implications are qualitatively challengingthough demonstrably surmountable-yet limited in number. For courts deciding cases, the requirements are more straightforward but affect a category of decisions that is growing exponentially.

Reading policy precedents provisionally requires courts to consider whether a previous decision held that a statute can bear only one meaning (therefore establishing binding law) or whether it merely adopted one reasonable construction of the law's terms (a policy choice). While this exercise is, of course, not always clear-cut (especially pre-Chevron, when courts often did not entertain such categories), parsing judicial precedents is a task for which courts are uniquely competent, institutionally and constitutionally. Indeed, since Chevron was decided, a number of courts of appeals have, in isolated but notable instances and often with vocal dissent, attempted limited inquiries of this sort by reading certain pre-Chevron decisions through a post-Chevron lens.222

220 Grocery Mfrs., 755 F.2d at 1000.

221 The D.C. Circuit also has suggested its openness to the provisional precedent theory. In Landmark Legal Found. v. IRS, the court stated that it would "decide for [itself] the best reading of [the statute]" and then upheld the reasonable agency construction. 267 F.3d 1132, 1136 (D.C. Cir. 2001). However, it recognized, yet "pretermitt[ed,] the issue of whether the IRS may later adopt a different-but nonetheless reasonable-interpretation." Id. (internal quotations omitted).

222 In particular, the Ninth and Tenth Circuits, in divisive en banc decisions decided a decade ago, both read the pre-Chevron Supreme Court decisions in Jim McNeff, Inc. v. Todd, 461 U.S. 260 (1983), and NLRB v. Local Union No. 103, Int'l Ass'n of Bridge, Structural \& Ornamental Iron Workers, 434 U.S. 335 (1978), as holding that deference was due to the pertinent NLRB policy, not that the Court was adopting that policy. See NLRB v. Viola Indus.-Elevator Div., Inc., 979 F.2d 1384, 1393-95 (10th Cir. 1992) (en banc); Mesa Verde Constr. Co. v. N. Cal. Dist. Council of Laborers, 861 F.2d 1124, 1129-30 (9th Cir. 1988) (en banc). That reading allowed them to defer to a new NLRB policy. See Viola Indus.-Elevator Div., 979 F.2d at 1395; Mesa Verde, 861 F.2d at 1134. Five other circuits have adopted their reading of those two cases. See supra note 183. Several circuits also have revisited specific pre-Chevron precedents of their own in light of post-Chevron concerns. See, e.g., NLRB v. Webcor Packaging, Inc., 118 F.3d 1115, 1123 n.8 (6th Cir. 1997) (deferring to agency interpretation contrary to earlier circuit cases that had given no deference to NLRB reading but instead had "set out to provide what they considered to be an enlightened view of the Act" (internal quotations omitted)); Reich v. D.M. Sabia Co., 90 
Yet in truth, the more important lessons of a theory of provisional stare decisis do not arise in figuring out how to read precedents currently on the books. Whether because of the passage of nearly two decades since the latest pre-Chevron cases, the uniformity with which courts now turn to Chevron's framework, or the fact that courts rarely strike down agency constructions of ambiguous statutes on substantive (rather than procedural) grounds, relatively few cases require this type of analysis. Mead's holding, however, will lead to a significant increase in decisions containing independent judicial constructions of statutes. 223 Thus, the prime significance of a theory of provisional stare decisis lies in how new opinions are written and understood.224

Under the strict incorporation approach, it makes no difference how carefully courts frame their conclusions (for example, by indicating whether they believe a statute can bear only one construction or many), because every time judges assign meaning to a statute in an individual case, they create binding precedent. If the Supreme Court is to be taken at its word, then, in the few months since Mead, the federal courts have, inter alia, incorporated into statutes judicial constructions of "sugar syrup," 225 of the "net present value" derived by energy company operations, ${ }^{226}$ of the types of gun mounts subject to the requirements of the Arsenal Act, ${ }^{227}$ and of the necessary medical qualifications for operating a vehicle. ${ }^{228}$ They also have, as a result of

F.3d 854, 860 (3d Cir. 1996) (according deference to new Occupational Safety and Health Administration interpretation contrary to circuit precedent taking into account Chevron's "new standard of review").

223 Indeed, on remand from the Supreme Court's decision in Mead itself, the Federal Circuit described "its independent responsibility to decide the legal issue regarding the proper meaning and scope of the [statutory] terms," Mead Corp. v. United States, 283 F.3d 1342, 1346 (Fed. Cir. 2002), in holding that imported day planners could not be classified as "bound diaries." See id. at 1350; see also Franklin v. United States, 289 F.3d 753, 757-58 (Fed. Cir. 2002) ("recogniz[ing] [court']s independent responsibility to decide the legal issue regarding the proper meaning and scope of the [statutory] terms" and finding that sand packets, which functioned exclusively to remove unwanted chlorine, bacteria, and acidity from water, were properly classified under Harmonized Tariff Schedule as goods used for filtering or purifying water (quoting Mead, 283 F.3d at 1346)).

The decisions in this and the following footnotes are but a handful of the post-Mead deference cases that are making their way through the federal courts. See also St. Luke's Methodist Hosp. v. Thompson, 182 F. Supp. 2d 765, 779 (N.D. Iowa 2001) (citing cases decided in months before Mead that applied Skidmore deference in light of Christensen v. Harris County, 529 U.S. 576 (2000), which initially suggested holding ultimately adopted in Mead).

224 Cf. Frederick Schauer, Precedent, 39 Stan. L. Rev. 571, 572-73 (1987) ("[A]n argument from precedent looks forward as well, asking us to view today's decision as a precedent for tomorrow's decisionmakers.").

225 Heartland By-Prods., Inc. v. United States, 264 F.3d 1126 (Fed. Cir. 2001).

226 Vill. of Bethany v. FERC, 276 F.3d 934 (7th Cir. 2002).

227 Am. Fed'n of Gov't Employees v. Rumsfeld, 262 F.3d 649 (7th Cir. 2001).

228 Tate v. Farmland Indus., Inc., 268 F.3d 989 (10th Cir. 2001). 
their "independent responsibility to decide the legal issue" in the absence of a regulation, ${ }^{229}$ enshrined into law forever (or until Congress musters the political will to act) a judicial definition of "bolts" and "screws."230 They repeatedly have eliminated future agency discretion to resolve acknowledged statutory ambiguity both when they adopted admittedly reasonable choices reached informally by agencies $^{231}$ and when they rejected such choices in favor of equally reasonable judicial ones. ${ }^{232}$

A theory of provisional precedent, on the other hand, requires cautious judicial decisionmaking because it draws a distinction between determinations of a statute's clear meaning and decisions of policy. Consistent with this theory, courts must state their holding with precision and should correspondingly limit their decisions to what is necessary to decide the case. Later courts must be able to discern clearly whether a decision mandates that a statute bear only one construction ${ }^{233}$ or that its terms are indeterminate; whether the earlier court found the agency's choice unreasonable or simply "d[id] not find the ... position to be persuasive" in light of Skidmore's factors, ${ }^{234}$ and whether the court's construction was the only permissible solution or one reached because the court saw "no reason to disturb [the agency]'s interpretation."235

229 Mead, 283 F.3d at 1346 (citing Rocknel Fastener, Inc. v. United States, 267 F.3d 1354, 1358 (Fed. Cir. 2001)); see also Student Loan Fund of Idaho, Inc. v. United States Dep't of Educ., 272 F.3d 1155, 1156-57 (9th Cir. 2001) (applying Skidmore deference after Mead and stating that court was required to "attempt to divine what the Congress meant" in relevant portions of Higher Education Act).

230 Rocknel Fastener, 267 F.3d at 1354. While withholding deference, the court derived its position in large part from a 1995 Customs Service publication on how to distinguish bolts from screws. Id. at 1357-58.

231 See Landmark Legal Found. v. IRS, 267 F.3d 1132, 1135-36 (D.C. Cir. 2001) (announcing that court "would owe deference to the IRS's interpretation" had it been reached "in a notice-and-comment rulemaking," yet "in light of $\mathrm{Mead}$, [the court] must decide for [itself] the best reading of the modifying clause").

232 See Catskill Mountains Chapter of Trout Unltd., Inc. v. City of New York, 273 F.3d 481 (2d Cir. 2001) (denying reasonable EPA position on dam discharges); Matz v. Household Int'l Tax Reduction Inv. Plan, 265 F.3d 572 (7th Cir. 2001) (holding, after Mead, that only nonvested participants should be counted in analysis of whether partial termination of pension plan took place, after previously holding, before $\mathrm{Mead}$, that statute was unclear and deferring to reasonable IRS position that both vested and nonvested participants could be counted).

233 See, e.g., McLaulin v. Comm'r, 276 F.3d 1269, 1275 n.12, (11th Cir. 2001) (identifying plain meaning of statute, which governs "[e]ven without deference").

234 Catskill Mountains, 273 F.3d at 491.

235 Heartland By-Prods., Inc. v. United States, 264 F.3d 1126, 1136 (Fed. Cir. 2001). It would be preposterous, for example, if a judicial construction as to the medical requirements for heavy vehicle operation, reached because a court "hesitate[d] to second guess a legitimate business judgment on the part of [the Department of Transportation]," were 


\section{c. Defending the Road Not Taken: Considering Objections}

Limiting precedential effect in a single doctrinal context to reflect Congress's intent may seem a radical proposal on several grounds. ${ }^{236}$ Accordingly, three objections, rooted in doctrinal, constitutional, and policy concerns, merit identification and response.

\section{i. Lack of Doctrinal Basis}

Some courts of appeals have suggested that the doctrine of stare decisis leaves no room for the notion that another branch of government can limit the binding nature of judicial constructions. Under that argument, there is no precedent for the conclusion that Chevron's presumption of legislative delegation "can[] compel a court to forgo the principle of stare decisis and abandon a construction previously made" 237 and thereby prescribe a relaxed rule of precedent.

Yet Supreme Court jurisprudence actually provides a solid foundation for a doctrine of provisional precedent in the administrative law context. Stare decisis, although usually "wise policy,"238 is "not an inexorable command."239 As Professor Monaghan has indicated, "stare decisis states a conditional obligation: precedent binds absent a showing of substantial countervailing considerations."240 The Court previously has found congressional intent to be one such countervailing factor. Specifically, in the antitrust context, the Court has relaxed the super-strong rule of precedent for interpretations of statutes because, in enacting the Sherman Anti-Trust Act, 241 "Congress expected the courts to give shape to the statute's broad mandate by

frozen as against subsequent DOT attempts to update it. Tate v. Farmland Indus., Inc., 268 F.3d 989, 994 (10th Cir. 2001).

236 At least, the proposition may appear radical if articulated forthrightly. See Polly J. Price, Precedent and Judicial Power After the Founding, 42 B.C. L. Rev. 81, 110 (2000) ("[W]e might ask what is the fuss about whether these cases are to be considered precedent, if binding decisions are not really binding-if courts can distinguish between 'narrow' holdings, 'central' holdings, 'essential' holdings, not to mention cases that are 'not controlling in the strictest sense." (footnotes omitted) (quoting Supreme Court cases)).

237 Aguirre v. INS, 79 F.3d 315, 317 (2d Cir. 1996).

238 Burnet v. Coronado Oil \& Gas Co., 285 U.S. 393, 406 (1932) (Brandeis, J., dissenting).

239 Agostini v. Felton, 521 U.S. 203, 235 (1997) (quoting Payne v. Tennessee, 501 U.S. 808,828 (1991)).

240 Henry Paul Monaghan, Stare Decisis and Constitutional Adjudication, 88 Colum. L. Rev. 723, 757 (1988); see, e.g., Burnet, 285 U.S. at 406 (Brandeis, J., dissenting) ("[I]n most matters it is more important that the applicable rule of law be settled than that it be settled right.").

241 Sherman Anti-Trust Act, ch. 647, 26 Stat. 209 (1890) (codified as amended at 15 U.S.C. $\$ \$ 1-7$ (2001)). 
drawing on common law tradition."242 This legislative purpose, it has held, reflects a "competing interest" 243 special to the antitrust context: "recognizing and adapting to changed circumstances and the lessons of accumulated experience."244 The legislative delegation of broad interpretive power, then, shifts the usual separation-of-powers requirements. Within the scope of the antitrust statute, the delegatee (here, the judiciary) may revisit and rework policy as circumstances demand, until the delegator (Congress) amends the statute. The even broader delegation of interpretive authority to agencies recognized in Chevron, undergirded by very similar "competing interest[s]"245 in flexible policy informed by experience, supports an analogous doctrinal revision.

\section{ii. The Rights of the Regulated Parties}

A second potential objection, informed by constitutional concerns, is that a doctrine of provisional precedent for administrative law decisions fails to respect the rights of regulated parties. The full Latin nomenclature of precedent doctrine-stare decisis et non quieta movere-identifies the reason to stand by the thing decided: so that the calm shall not be disturbed.246 That value is at its "acme in cases involving property and contract rights, where reliance interests are involved,"247 for, as the Supreme Court explained a century and a half ago, "every one would suppose that after the decision of this court, in a matter of that kind, he might safely enter into contracts, upon the faith that rights thus acquired would not be disturbed." 248 If a party may not rely on the constancy of the construction of a regulatory statute, that expectation is disturbed.

This critique, however, is more accurately directed at Chevron's broader understanding of private rights under a system of public regu-

242 State Oil Co. v. Khan, 522 U.S. 3, 20-21 (1997) (emphasis added) (internal quotation omitted); see Frank H. Easterbrook, Stability and Reliability in Judicial Decisions, 73 Cornell L. Rev. 422, 426-27 (1988) (distinguishing "statutes, such as the Sherman Act, that transfer a dollop of law-making power to the courts after the fashion of the common law," from "statutes that might be thought to contain rules rather than an allocation of power to make rules").

243 State Oil, 522 U.S. at 20.

244 Id.

$245 \mathrm{Id}$.

246 See Richard H. Fallon, Jr., Stare Decisis and the Constitution: An Essay on Constitutional Methodology, 76 N.Y.U. L. Rev. 570, 570 n.1 (2001) (providing translation of stare decisis).

247 Payne v. Tennessee, 501 U.S. 808, 828 (1991).

248 The Propeller Genesee Chief v. Fitzhugh, 53 U.S. (12 How.) 443, 458 (1851) ("For if the law, as pronounced by the court, ought not to stand, it is in the power of the legislature to amend it, without impairing rights acquired under it."). 
lation and it already has been accounted for in that general scheme. Expectations, of course, arise from interests created by governing law. 249 While stare decisis is generally rooted in such "policy considerations militat[ing] in favor of continuity and predictability in the law,"250 administrative policy after Chevron is governed by a different directive: An agency "must consider varying interpretations and the wisdom of its policy on a continuing basis" and "must be given ample latitude to adapt ... rules and policies to the demands of changing circumstances." 251

Consistent with the understanding that agencies should revisit, and may reform, governing rules and policies according to policy dictates, administrative law jurisprudence protects private interests in two ways. First, the law limits the retroactive application of agency decisions in a number of contexts, particularly in administrative adjudication. ${ }^{252}$ Second, Chevron's rule of flexibility is expressly circumscribed by the Supreme Court's holding that "[s]udden and unexplained change, or change that does not take account of legitimate reliance on prior interpretation, may be 'arbitrary, capricious [or] an abuse of discretion." 253 At a minimum, parties affected by a policy shift would be ensured both notice of possible changes and an opportunity to be heard, because after $\mathrm{Mead}$, an agency must engage in relatively formal procedures to ensure judicial deference to revised interpretations.

\section{iii. Policy Alternatives After Mead}

Finally, it is worth making explicit an argument implicitly rejected by this Article: that Mead might be read alternatively to suggest a different notion of Congress's intent in delegating authority to agencies. The argument would proceed as follows: Perhaps Congress should be understood to delegate agencies power to construe ambiguous statutory terms if, but only if, certain conditions of formality are satisfied before a court interprets the terms on its own. What Con-

249 See Bd. of Regents v. Roth of State Colls., 408 U.S. 564, 577 (1972) (

Property interests, of course, are not created by the Constitution. Rather, they are created and their dimensions are defined by existing rules or understandings that stem from an independent source such as state law-rules or understandings that secure certain benefits and that support claims of entitlement to those benefits.)

250 Boys Mkts., Inc. v. Retail Clerks Union, Local 770, 398 U.S. 235, 240 (1970).

251 Rust v. Sullivan, 500 U.S. 173, 186-87 (1991) (internal citations omitted).

252 See ARA Servs., Inc. v. NLRB, 71 F.3d 129, 135-36 (4th Cir. 1995) (discussing limitations on retroactive enforcement of Board rules); Laborers' Int'l Union v. Foster Wheeler Corp., 26 F.3d 375, 385-95 (3d Cir. 1994) (same).

253 Smiley v. Citibank (S.D.), N.A., 517 U.S. 735, 742 (1996) (quoting 5 U.S.C. $\S 706(2)(\mathrm{A})(2001)$ ) (internal citations omitted). 
gress really intends, then, is only to give agencies a window of discretion, after which they lose their interpretive authority. At that time, Congress would want judicial interpretations to control, in order to achieve the recognized benefits of settlement.

Certainly, this suggestion stands at odds with the structural premises adopted by the Chevron Court ${ }^{254}$ and that decision's rule of flexibility in administrative policy. ${ }^{255}$ Yet because imputing an "intent" to Congress reflects policy concerns external to any particular judicial doctrine, the suggestion that Mead be read in this manner requires some mention of practical and normative arguments not specific to the Chevron context. ${ }^{256}$

Practically, requiring more formal resolution of all statutory ambiguity would render impossible the realization of express congressional directives. Congress's regulatory mandates would remain unenforced by agencies overburdened by process obligations.

More fundamentally, it makes little sense to pit agencies in a race against courts because of both the inapt mechanism and the inappropriate competitor. Setting aside any debate over standards of review, it is clear that implementing broad statutory directives requires detailed policy decisions; those choices involve not only a knowledge of the law, but the ability both to consider ideals informed by economics and social and hard science, and to make pragmatic choices shaped by changing political, social, and market realities. Deciding the timing of policymaking by contest removes those decisions from the ideals and the realities alike. Denying agencies policymaking power when the judiciary rules on an issue first freezes in place decisions made by an institution with an avowedly inferior ability to assess social conditions $^{257}$ and without the constitutional capacity to make political choices. By contrast, a doctrine of provisional precedent demands

254 See supra Part I.B.

255 See supra notes 93-106 and accompanying text.

256 As discussed in supra note 59 , this Article principally concerns itself with tensions between the incorporation theory of precedent and the Court's own doctrinal account of the judicial deference required by Chevron.

257 See Fed. Power Comm'n v. Fla. Power \& Light Co., 404 U.S. 453, 463 (1972) (noting agency ability to assess "engineering and scientific considerations" and Congress's "appreciation of such different institutional capacities" (internal quotations omitted)); cf. Gen. Motors Corp. v. Tracy, 519 U.S. 278, 309 (1997) ("Congress has the capacity to investigate and analyze facts beyond anything the Judiciary could match, joined with the authority of the commerce power to run economic risks that the Judiciary should confront only when the constitutional or statutory mandate for judicial choice is clear."). See generally Stuart Minor Benjamin, Proactive Legislation and the First Amendment, 99 Mich. L. Rev. 281 (2000) (discussing comparative institutional capabilities); Note, Deference to Legislative Fact Determinations in First Amendment Cases After Turner Broadcasting, 111 Harv. L. Rev. 2312 (1998) (written by Kenneth A. Bamberger) (same). 
that courts recognize explicitly their comparative disadvantage and permits responsiveness to changing circumstances by regulatory policy.

Significantly, judging according to such a doctrine also promotes many of the very values that undergird the notion of precedent. ${ }^{258}$ It reflects precedent's value as a "limit [on] judicial power delegated to the courts by Article III," 259 preventing the judiciary's exercise of "arbitrary discretion" as feared by Hamilton. ${ }^{260}$ It ensures that courts do not, in error, encroach on the legislative province. ${ }^{261}$ And it protects "the actual and perceived integrity of the judicial process." 262 For as Justice Douglas explained in his discussion of stare decisis, "[a] judiciary that discloses what it is doing and why it does it will breed understanding. And confidence based on understanding is more enduring than confidence based on awe."263

\section{CONCLUSION}

A "Midas Touch" conception of judicial precedent (whatever a court reaches is incorporated into positive law) permits the judiciary to commandeer the discretion delegated to agencies at the expense of the recognized intent of Congress. In so doing, it seriously undermines the principal goals underlying the delegation of authority to agencies: the development of coherent, responsible, national policy guided by administrative expertise and political responsiveness.

After Mead, strict incorporation promises particularly widespread disruption of administrative flexibility. And the comparative infrequency of congressional or Supreme Court action "overturning" judicial precedents renders incorporation, in most cases, permanent. The incorporation approach poses a threat to the viability of a functioning administrative state.

258 See supra Part I.A.

259 Anastasoff v. United States, 223 F.3d 898, 900 (8th Cir.), vacated as moot en banc, 235 F.3d 1054 (8th Cir. 2000).

260 Patterson v. McLean Credit Union, 491 U.S. 164, 172 (1989) (acknowledging value of stare decisis in "preserving a judicial system that is not based upon 'an arbitrary discretion'" (quoting The Federalist No. 78, supra note 28, bk. 2, at 105)).

261 Neal v. United States, 516 U.S. 284, 295. ("[W]e give great weight to stare decisis in the area of statutory construction [because] 'Congress is free to change this Court's interpretation of its legislation." (quoting Ill. Brick Co. v. Illinois, 431 U.S. 720, 736 (1977))).

262 Payne v. Tennessee, 501 U.S. 808, 827 (1991).

263 Hon. William O. Douglas, Stare Decisis, Eighth Annual Benjamin N. Cardozo Lecture Delivered Before the Association of the Bar of the City of New York (Apr. 12, 1949), in 1 The Benjamin N. Cardozo Memorial Lectures, at 263, 290 (1995). See generally David L. Shapiro, In Defense of Judicial Candor, 100 Harv. L. Rev. 731, 741 (1987) (discussing improper treatment of precedent). 
The federalism model suggests an alternative framework for the review of agency action, under which judicial determinations of policy are binding on courts and agencies only until the agency delegated interpretive authority by Congress makes its own interpretation in a form deserving of deference. Such a theory of provisional precedent gives effect to Chevron's admonition that "[ $t]$ he responsibilities for assessing the wisdom of such policy choices and resolving the struggle between competing views of the public interest are not judicial ones." 264 And such a theory ensures that regulatory policy is not left to "the contingencies of judicial review and of litigation," 265 but is rightly determined by considerations of the public interest.

264 Chevron U.S.A., Inc. v. Natural Res. Def. Council, Inc., 467 U.S. 837, 866 (1984).

265 FCC v. Pottsville Broad. Co., 309 U.S. 134, 145 (1940). 